\title{
Schwann Cells in Neuromuscular Junction Formation and Maintenance
}

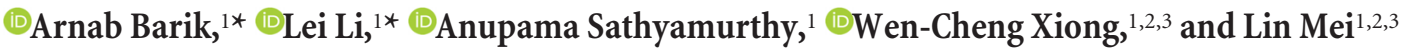 \\ ${ }^{1}$ Department of Neuroscience and Regenerative Medicine and ${ }^{2}$ Department of Neurology, Medical College of Georgia, Augusta University, Augusta, Georgia \\ 30912, and ${ }^{3}$ Charlie Norwood Veterans Administration Medical Center, Augusta, Georgia 30904
}

The neuromuscular junction (NMJ) is a tripartite synapse that is formed by motor nerve terminals, postjunctional muscle membranes, and terminal Schwann cells (TSCs) that cover the nerve-muscle contact. NMJ formation requires intimate communications among the three different components. Unlike nerve-muscle interaction, which has been well characterized, less is known about the role of SCs in NMJ formation and maintenance. We show that SCs in mice lead nerve terminals to prepatterned AChRs. Ablating SCs at E8.5 (i.e., prior nerve arrival at the clusters) had little effect on aneural AChR clusters at E13.5, suggesting that SCs may not be necessary for aneural clusters. SC ablation at E12.5, a time when phrenic nerves approach muscle fibers, resulted in smaller and fewer nerve-induced AChR clusters; however, SC ablation at E15.5 reduced AChR cluster size but had no effect on cluster density, suggesting that SCs are involved in AChR cluster maturation. Miniature endplate potential amplitude, but not frequency, was reduced when SCs were ablated at E15.5, suggesting that postsynaptic alterations may occur ahead of presynaptic deficits. Finally, ablation of SCs at P30, after NMJ maturation, led to NMJ fragmentation and neuromuscular transmission deficits. Miniature endplate potential amplitude was reduced $3 \mathrm{~d}$ after SC ablation, but both amplitude and frequency were reduced $6 \mathrm{~d}$ after. Together, these results indicate that SCs are not only required for NMJ formation, but also necessary for its maintenance; and postsynaptic function and structure appeared to be more sensitive to SC ablation.

Key words: AChRs; glia; NMJ; Schwann cell

\section{Significance Statement}

Neuromuscular junctions (NMJs) are critical for survival and daily functioning. Defects in NMJ formation during development or maintenance in adulthood result in debilitating neuromuscular disorders. The role of Schwann cells (SCs) in NMJ formation and maintenance was not well understood. We genetically ablated SCs during development and after NMJ formation to investigate the consequences of the ablation. This study reveals a critical role of SCs in NMJ formation as well as maintenance.

\section{Introduction}

The neuromuscular junction (NMJ) is a tripartite synapse, which includes motor nerve terminals where acetylcholine is released, postjunctional membranes where AChRs are concentrated, and terminal Schwann cells (TSCs; or perisynaptic Schwann cells), which cover the nerve-muscle junction (Sanes and Lichtman, 2001; Wu et al., 2010). Large and easily accessed experimentally,

\footnotetext{
Received Jan. 16, 2016; revised July 11, 2016; accepted July 14, 2016.

Author contributions: A.B., L.L., W.-C.X., and L.M. designed research;A.B., L.L., and A.S. performed research;A.B., L.L., A.S., and W.-C.X. analyzed data; A.B. and L.M. wrote the paper.

This study was supported in part by Grants from the National Institutes of Health and Veterans Affairs. L.M. is a Georgia Research Alliance Eminent Scholar in Neuroscience.

The authors declare no competing financial interests.

${ }^{*}$ A.B. and L.L. contributed equally to this study.

Correspondence should be addressed to Dr. Lin Mei, Department of Neuroscience and Regenerative Medicine, Medical College of Georgia, Augusta University, 1459 Laney Walker Blvd, Augusta, GA 30912. E-mail: Imei@augusta.edu.

DOI:10.1523/JNEUROSCI.0174-16.2016

Copyright (C) 2016 the authors $\quad 0270-6474 / 16 / 369770-12 \$ 15.00 / 0$
}

it has contributed greatly to the understanding of mechanisms of synapse formation and neurotransmission. Abnormal NMJ formation, maintenance, or function result in neurological disorders, including congenital myasthenic syndrome and myasthenia gravis (Engel et al., 2003).

NMJ formation requires intimate interaction between motoneurons and skeletal muscle fibers. Before the arrival of motor nerve terminals, around embryonic day 12.5 (E12.5) in mice, muscle fibers of diaphragms form aneural, primitive AChR clusters, which are dotted in the middle region, a phenomenon called prepatterning of muscle fibers (Lin et al., 2001; Yang et al., 2001). The aneural clusters are thought to contribute to forming larger, synaptic AChR aggregates, in response to innervation, and outline a region that attract nerve terminals (Flanagan-Steet et al., 2005; Jing et al., 2009). Nerve induction of AChR clustering requires agrin, an extracellular proteoglycan, which acts by stimulating the Lrp4-MuSK receptor complex (Godfrey et al., 1984; Nitkin et al., 1987; McMahan, 1990; Ruegg et al., 1992; Kim et al., 2008; Zhang et al., 2008; Zong et al., 2012). Primitive, extrasyn- 
aptic AChR clusters are dispersed by muscle activity, caused by AChR activation by ACh (Avila et al., 1989; Misgeld et al., 2002; Brandon et al., 2003). In addition, presynaptic differentiation is regulated by signals from nerve terminals, secreted musclederived factors, including FGF and Slit2, and muscle proteins, including Lrp4, MuSK, intergrin, and $\beta$-catenin (Schwander et al., 2004; Fox et al., 2007; Kim and Burden, 2008; Li et al., 2008; Liu et al., 2012; Wu et al., 2012, 2015; Yumoto et al., 2012).

The role of SCs in NMJ formation and function has begun to be appreciated (Feng and Ko, 2008b; Griffin and Thompson, 2008; Ko and Robitaille, 2015). In Drosophila, glia release Wnt to regulate glutamate receptor clustering in the muscle and a TGF- $\beta$ ligand to activate a retrograde pathway for presynaptic differentiation (Fuentes-Medel et al., 2012; Kerr et al., 2014). After ablation of TSCs in frog, nerve terminal growth is reduced and developing NMJs retract or withdraw (Reddy et al., 2003). Frog SCs were shown to promote synaptogenesis by a battery of secretable factors, including agrin and TGF- $\beta 1$ (Yang et al., 2001; Peng et al., 2003; Feng and Ko, 2008a). After NMJ formation, TSCs contribute to synapse elimination at NMJs (Bishop et al., 2004; Tapia et al., 2012; Darabid et al., 2013; Smith et al., 2013) and regulate both efficacy and structural plasticity of the NMJ presumably by decoding synaptic transmission and by interacting with trophic factors (Robitaille, 1998; Todd et al., 2010; Ko and Robitaille, 2015). After injury, TSCs sprout to guide regenerating motor axons to the original site of innervation (Reynolds and Woolf, 1992; Son and Thompson, 1995a, b; O'Malley et al., 1999; Nguyen et al., 2002). Nevertheless, the role of SCs in NMJ formation in mammals has been unclear. Mutation of $\operatorname{ErbB2}$, a receptor kinase critical for neuregulin signaling, impairs SC formation and migration in mice, causing SC ablation and NMJ deficits (Morris et al., 1999; Woldeyesus et al., 1999; W. Lin et al., 2000). However, the NMJ deficits could be secondary because, in these mutant mice, motoneurons cannot survive and motor nerves retract.

In this study, we genetically labeled SCs in mice and investigated their interaction with motor nerve terminals and found that, in mammals, SCs are positioned ahead of developing axons during NMJ formation. Next, by specific expression of diphtheria toxin A, we ablated SCs at critical times during NMJ formation: before and shortly after innervation and after NMJ maturation. We investigated the consequences of SC loss by characterizing markers of postsynaptic as well as presynaptic differentiation. Neuromuscular transmission was also used to determine whether morphological changes were accompanied by functional deficiencies or vice versa and whether presynaptic or postsynaptic deficits occurred first. Results indicate that SCs are critical for NMJ formation. Loss of SCs appears to alter postsynaptic function initially, which is followed by presynaptic deficits.

\section{Materials and Methods}

Mouse strains. D2.Cg-Tg (Plp-Cre/ERT)3Pop/SjJ (stock\#024701), B6.129S-

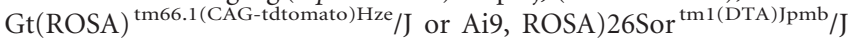
(stock \#005975), B6.Cg-Tg(Hb9-GFP)1Tmj/J (stock \#005029), and FVB.Cg-Tg (HSA-Cre)79Jme/J (stock \#006139) mice were purchased from The Jackson Laboratory (Miniou et al., 1999; Wichterle et al., 2002; Doerflinger et al., 2003; Ivanova et al., 2005; Madisen et al., 2010; Bean et al., 2014; Wu et al., 2015). Genotyping was performed as described previously (Barik et al., 2014b; Sathyamurthy et al., 2015). For Cre activation in embryos, pregnant mice were administered tamoxifen (TMX) by oral gavage at 100 $\mathrm{mg} / \mathrm{kg}$ of body weight. For Cre activation in neonatal mice, pups were given TMX by oral gavage at the same dose. The number of pups per delivery was reduced for TMX-treated pregnant, regardless of genotypes, probably due to TMX toxicity (Huh et al., 2010). Mice were housed in a room with a $12 \mathrm{~h}$ light/dark cycle with ad libitum access to water and rodent chow diet (Diet
1/4 7097, Harlan Teklad). Adult male mice or embryonic and neonatal mice of either sex were studied. Experimental procedures were approved by the Institutional Animal Care and Use Committee of Augusta University.

Light microscopic analysis and quantification. Entire diaphragms with ribs or TA muscles were freshly dissected from mice and fixed in $4 \%$ PFA in PBS, pH 7.3, at $4^{\circ} \mathrm{C}$ for $3 \mathrm{~d}$, rinsed with $\mathrm{PBS}, \mathrm{pH} 7.3$, at $25^{\circ} \mathrm{C}$, and incubated with $0.1 \mathrm{~m}$ glycine in $\mathrm{PBS}$ for $1 \mathrm{~h}$ at room temperature. The $\mathrm{pH}$ of PBS, including PFA, was critical for proper staining. After rinse with $0.5 \%$ Triton X-100 in PBS, muscles or teased fibers were incubated in blocking buffer (5\% BSA and 1\% Triton X-100 in PBS) for $3 \mathrm{~h}$ at room temperature. Tissues were then incubated with primary antibodies in the blocking buffer overnight at room temperature on a rotating shaker. Primary antibodies included: neurofilament (NF-H) (rabbit polyclonal, 1:1000, ab7795, Millipore or mouse monoclonal, \#2H3, Developmental Studies Hybridoma Bank, University of Iowa), MF20 (mouse monoclonal,1:200 Developmental Studies Hybridoma Bank, University of Iowa), S100 $\beta$ (1:1000, Z0311, DAKO) and synaptophysin (SYN) (1:1000, IR660, DAKO). After washing 3 times for $1 \mathrm{~h}$ each with $0.5 \%$ Triton X-100 in PBS, tissues were incubated with AlexaFluor-488-conjugated goat antibody against rabbit or mouse IgG (1:500, A-11008 and A-11001, respectively, Invitrogen), or AlexaFluor-633-conjugated goat antibody against rabbit or mouse IgG (1:500, A-21070 and A-21052, respectively, Invitrogen), and rhodamine- or Alexa-488 conjugated $\alpha$-bungarotoxin (T-1175 and B-13422, respectively, Invitrogen) for $1 \mathrm{~h}$ in PBS with $0.5 \%$ Triton X-100. Tissues were washed thrice for $1 \mathrm{~h}$ each with $0.5 \%$ Triton $\mathrm{X}-100$ in PBS, rinsed once with PBS, and flat-mounted in Vectashield mounting medium (H-1000, Vector Laboratories). $z$-serial images were collected at $40 \times$ or $63 \times$ with a Zeiss confocal laser scanning microscope (LSM 510 META 3.2) and collapsed into a single image.

For imaging quantitative analysis, images were captured at a subsaturating level and quantified using LSM Image Browser (Zeiss) and/or ImageJ/FIJI (National Institutes of Health) software (Barik et al., 2014b; Wu et al., 2015). To characterize the relationships between nerve terminals and SCs versus aneural AChR clusters, we measured the shortest distance between nerve terminals or SCs and closest AChR clusters. We also counted the number of AChR clusters in an area of $100 \mu \mathrm{m}^{2}$ in contact with the last $100 \mu \mathrm{m}$ of nerve terminals or associated SCs. To quantify the area of muscle fibers that was contacted by the nerve terminals and SCs, we measured areas that were occupied by last $100 \mu \mathrm{m}$ nerve terminals and associated SCs. The distance between nerve terminals and SCs was defined as that between the tip of a nerve terminal and farthest edge of SCs in the same direction as of last $50 \mu \mathrm{m}$ of nerve terminals. S100 $\beta$ staining in an area of $100 \mu \mathrm{m}^{2}$ along axons (axonal) or at terminals was quantified.

Electron microscopy analysis. Electron microscopy was performed as described previously (Shen et al., 2013; Barik et al., 2014b; Wu et al., 2015). Diaphragms were lightly stained with rhodamine-conjugated $\alpha$-bungarotoxin (R-BTX) $\left(1: 1000\right.$, in ice-cold PBS at $\left.4^{\circ} \mathrm{C}\right)$ to mark the central region where NMJs are enriched. The regions were dissected with a microscalpel (Harvard Apparatus, \#PY2 56-5673) under a Leica fluorescent dissection scope and fixed (blocks of $\sim 4 \mathrm{~mm} \times 4 \mathrm{~mm}$ ) in $2 \%$ glutaraldehyde and $2 \%$ PFA in $0.1 \mathrm{M} \mathrm{PBS}$ overnight at $4{ }^{\circ} \mathrm{C}$. Tissues were further fixed in sodium cacodylate-buffered, $\mathrm{pH} 7.3,1 \%$ osmium tetroxide for $1 \mathrm{~h}$ at $25^{\circ} \mathrm{C}$. Fixed tissues were washed $3 \times$ with $\mathrm{PBS}$ and subjected to dehydration through a series of ethanol: $30 \%, 50 \%, 70 \%, 80 \%, 90 \%$, and $100 \%$. After 3 rinses with $100 \%$ propylene oxide, samples were embedded in plastic resin (EM-bed 812, EM Sciences). Serial sections (1-2 $\mu \mathrm{m})$ were stained with $1 \%$ toluidine blue to identify motor nerves and were cut into ultrathin sections. Alternate longitudinal sections were chosen to avoid duplicity of obtaining images from same terminals. Sections were mounted on $200 \mu \mathrm{m}$ mesh unsupported copper grids and stained with a solution containing 3\% uranyl acetate, 50\% methanol, $2.6 \%$ lead nitrate, and 3.5\% sodium citrate, $\mathrm{pH}$ 12.0. Electron micrographs were taken using a JEOL 100CXII operated at $80 \mathrm{KeV}$.

Electromyography and electrophysiological recording. Electromyographic recording was performed as described previously (Shen et al., 2013; Barik et al., 2014b). Briefly, mice were anesthetized with ketamine and xylazine (i.p., $80 \mathrm{mg} / \mathrm{kg}$ and $20 \mathrm{mg} / \mathrm{kg}$, respectively). For electro- 
A

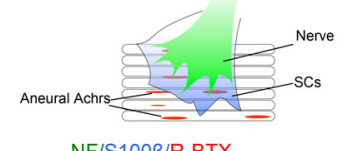

NF/S100ß/R-BTX

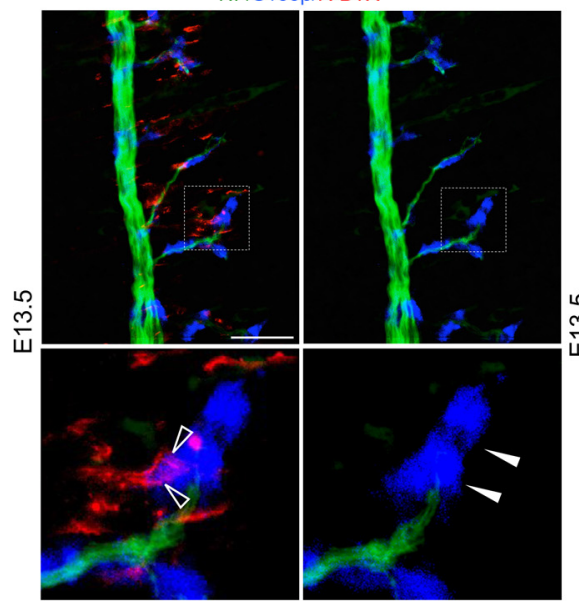

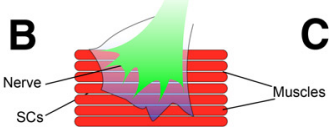

HSA-tdTomato;Hb9-GFP/P75

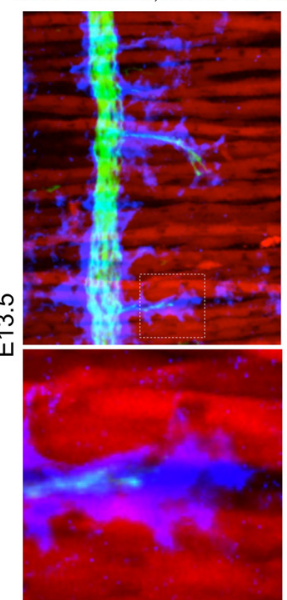

C

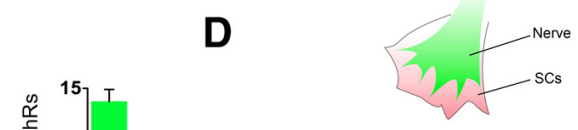

\section{$\frac{\mathscr{r}}{5}$}
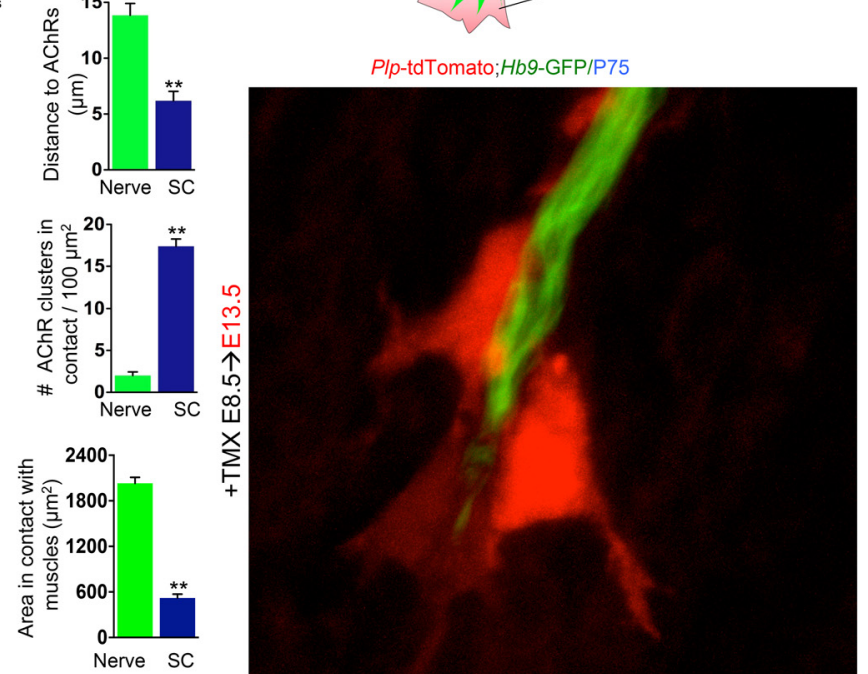

Figure 1. Extension of SCs ahead of axons in developing muscles. $A$, Left panels, E13.5 diaphragms were stained whole mount with R-BTX (red) to label AChR clusters, NF antibody to label nerves, and $\mathrm{S} 100 \beta$ antibody (blue) to label SCs. Empty arrowheads indicate the interaction between aneural AChR clusters and SCs. Solid arrowheads indicate SCS at nerve terminals. $\boldsymbol{B}$, SCS labeled by anti-P75 antibody (blue) were ahead of nerve terminals (green, visualized by GFP) in HSA-tdTomato;Hb9-GFP mice, making contact with muscles expressing tdTomato (red). C, More aneural AChR clusters were in contact with SCs than those in contact with nerve terminals. The distance from AChR clusters to SCs was smaller than that to nerve terminals. SCs overlapped with more muscle surface than nerve terminals. Data are mean \pm SEM. ${ }^{* *} p<0.001$ (Student's $t$ test). $n=7$ embryos per group. Scale bar, $100 \mu m$. D, SCs were labeled by tdTomato (red) whose expression was induced in TMX-treated PIp-tdTomato mice. Nerve axons were visualized by GFP in Hb9-GFP mice. tdTomato-labeled SCs extended ahead of GFP-filled nerve terminals.

myography, the stimulation electrode was inserted into the left thigh close to the path of sciatic nerves. A reference electrode was inserted near the Achille's tendon while the recording needle electrode was inserted into the middle of the gastrocnemius. Supramaximal stimulation was applied to the sciatic nerve with a train of 10 stimuli at 2, 5, 10,20, or 40 $\mathrm{Hz}$. Compound muscle action potentials (CMAPs) were collected by the reference and recording electrodes via Axopatch 200B amplifier and Digidata 1322A (Molecular Devices). Peak to peak amplitudes were analyzed in Clampfit 9.2 (Molecular Devices). During experiments, mice were maintained at $37^{\circ} \mathrm{C}$ on a heating pad.

Electrophysiological recording was performed as described previously (Shen et al., 2013; Barik et al., 2014b). Diaphragms with ribs with intact phrenic nerves were dissected in oxygenated $\left(95 \% \mathrm{O}_{2} / 5 \% \mathrm{CO}_{2}\right)$ Ringer's solution ( $136.8 \mathrm{~mm} \mathrm{NaCl}, 5 \mathrm{~mm} \mathrm{KCl}, 12 \mathrm{~mm} \mathrm{NaHCO}{ }_{3}, 1 \mathrm{~mm} \mathrm{NaH} \mathrm{PO}_{4}$, $1 \mathrm{mM} \mathrm{MgCl}_{2}, 2 \mathrm{mM} \mathrm{CaCl}_{2}$, and $11 \mathrm{~mm}$ D-glucose, $\mathrm{pH} 7.3$ ) and pinned on Sylgard gel in a dish perfused with oxygenated Ringer's solution. To measure miniature endplate potential (mEPP), microelectrodes $(20-50$ $\mathrm{M} \Omega$, when filled with $3 \mathrm{M} \mathrm{KCl}$ ) were pierced into the center of muscle fibers with the resting potential between -45 and $-55 \mathrm{mV}$. To evoke endplate potentials, phrenic nerves were stimulated by a suction electrode with suprathreshold square pulses $(0.1 \mathrm{~ms})$ using Master- 8 (A.M.P.I.). Data were collected with axonpatch 200B amplifier (Molecular Devices), digitized with Digidata 1322A (Molecular Devices), and analyzed using pClamp 9.2 (Molecular Devices).

Statistical analysis. Two-tailed, Student's $t$ test was used to compare data between two groups. Unless otherwise indicated, data are expressed as mean \pm SEM, and considered statistically significant at $p<0.05$.

\section{Results}

\section{SCs in advance of motoneuron terminals}

Synaptic SCs were found to be ahead of regenerating axons after nerve injury (Son and Thompson, 1995a, b). The relationship between SCs and axons in developing mammals is unknown. We stained whole-mount diaphragms of E13.5 mice with antibodies against NF to label axons and against $S 100 \beta$ to label SCs, and with R-BTX to label AChRs. As shown in Figure 1A, SCs (blue) was ahead of axon terminals, some of which were in contact with aneural AChR clusters. At this stage, aneural clusters were closer to SCs than nerve terminals; accordingly, AChR clusters in contact with nerve terminals were fewer than those in contact with SCs (Fig. $1 A, C$ ). Because S100 $\beta$ expression varies through SC development, we used a different marker of SCs, P75 (Jessen and Mirsky, 2005; Wanner et al., 2006), to further characterize this phenomenon. Axons were genetically labeled by Hb9-GFP (Wichterle et al., 2002) and muscle fibers were visualized HSA::Cre;Rosa26-LSL-tdTomato (Ai9) (Miniou et al., 1999; Madisen et al., 2010). As shown in Figure 1B, P75-positive SCs extended well ahead of nerve terminals. The area of contact between SCs and muscle fibers was greater than that between nerve terminals and muscle fibers (Fig. $1 C$ ).

Finally, we attempted to genetically label SCs by crossing $P l p$-Cre ${ }^{\text {erT2 }}$ mice, in which TMX-inducible Cre expression is restricted to SCs (Doerflinger et al., 2003; Brill et al., 2011), with Rosa26-LSL-tdTomato mice. Resulting Plp-tdTomato mice were treated with TMX (at E8.5). One day after TMX treatment (i.e., at E9.5), tdTomato was detectable in the CNS and the dorsal region of the spinal cord, presumably in SC progenitor cells (Fig. 2A,B). To verify that tdTomato was indeed expressed in SCs, we stained whole-mount diaphragms of P0 Plp-tdTomato mice that had been administered with TMX at E8.5. TdTomato was costained with $\mathrm{S} 100 \beta$, a marker of mature SCs (Fig. $2 C$ ). The complete registration between $\mathrm{S} 100 \beta$ and tdTomato suggests that the latter fluorescence protein could serve as an indicator of SCs. Next, $\mathrm{Plp}$-tdTomato mice were bred with $\mathrm{Hb}$ 9-GFP mice, where motor axons were labeled with GFP. $P l p$-tdTomato;Hb9-GFP mice were treated with TMX at E8.5 and examined at E13.5. As shown in Figure $1 D$, tdTomato-labeled SCs were ahead of nerve terminals, which were labeled by GFP. Together, these results demonstrate that, in mammals, SCs are ahead of developing axons before NMJ formation. 
A

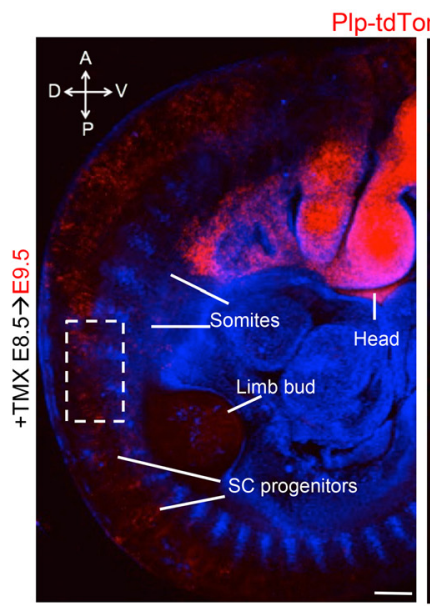

B

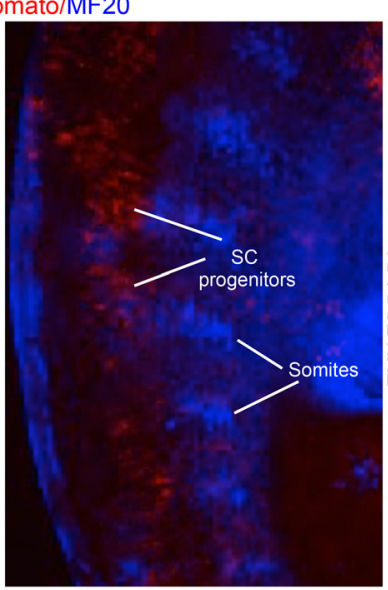

C

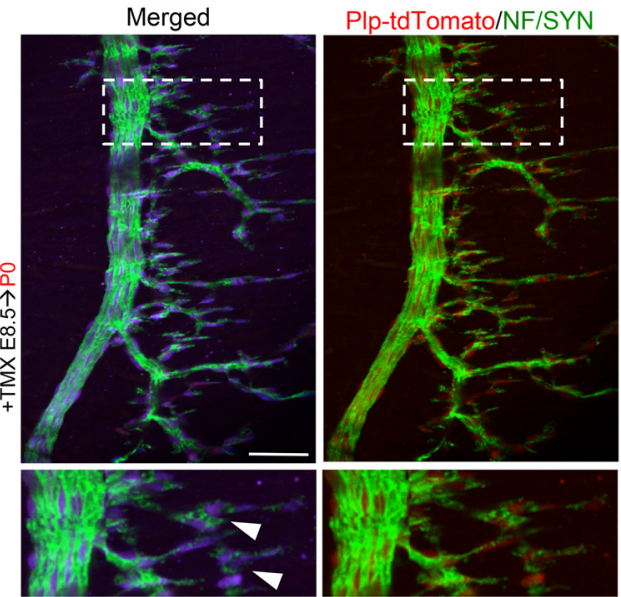

S100ß/NF/SYN

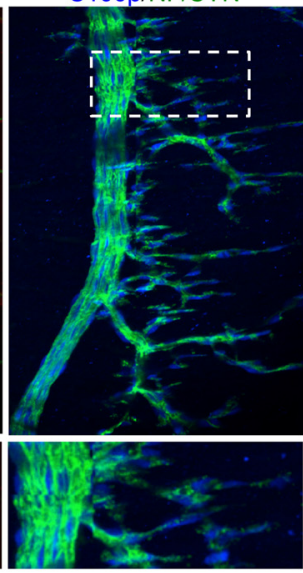

Figure 2. Expression of tdTomato in SC progenitor cells and SCS. A, Pregnant Plp-tdTomato mice were administered with TMX at E8.5, and embryos were harvested at E9.5. Shown is a representative image of whole-mount embryo at E9.5. tdTomato labeled SC progenitors (neural crest cells) dorsal to somites, visualized by anti-myosin I antibody (MF20) (blue). A, Anterior; $P$, posterior; D, dorsal; V, ventral. $B$, Enlarged image of the boxed area in $A$. C, Colocalization of tdTomato with S100 $\beta$ in muscles. Pregnant Plp-tdTomato mice were administered with TMX at E8.5, and diaphragms were isolated from PO pups and stained whole mount with a combination of NF/SYN antibodies and S100 $\beta$ (green and blue, respectively). Arrowheads indicate cells that are positive for tdTomato and $\mathrm{S} 100 \beta$. Scale bar, $100 \mu \mathrm{m}$.

A

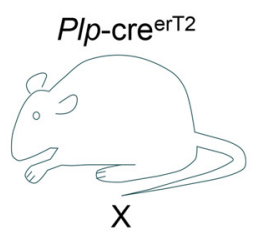

Rosa26-LSL-DTA

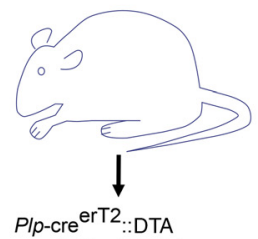

(PIp-DTA)

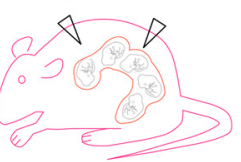

B

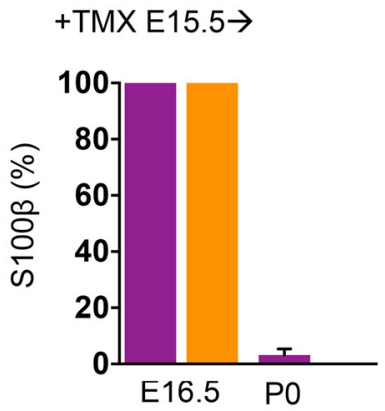

D

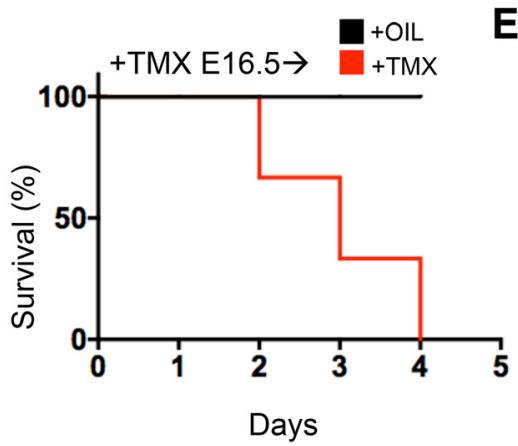

C

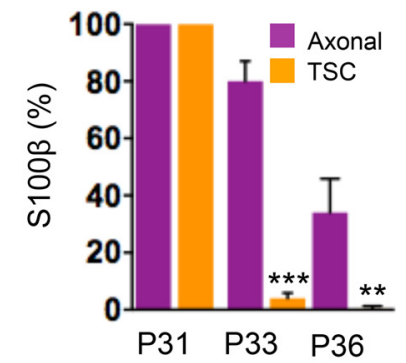

E

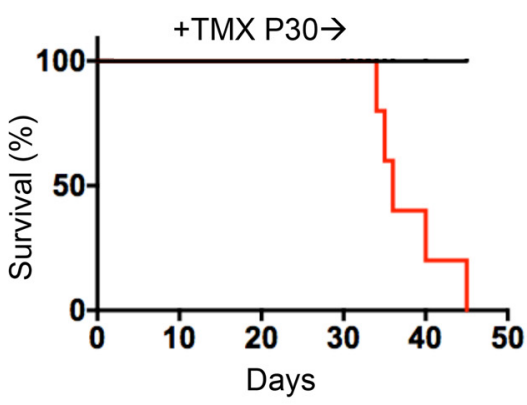

Figure 3. Genetic ablation of SCS in a time-dependent manner. $A$, Schematic diagram for breeding strategy. $B, C$, Reduced $S 100 \beta$ staining associated with axons and at the terminals. $S 100 \beta$ staining in an area of $100 \mu \mathrm{m}^{2}$ along axons (axonal) or at terminals was quantified, with oil-treated samples as $100 \%$. Reduced S100 $\beta$ staining indicates reduced axonal SCs and TSCs in PIp-DTA mice following TMX administration. Data are mean \pm SEM. ${ }^{* * *} p<0.0001$ (Student's test). ${ }^{* *} p<0.001$ (Student's test). $n=5$ mice per group. $\boldsymbol{D}, \boldsymbol{E}$, Kaplan-Meier survival curves. Plp-DTA mice were treated with oil and TMX at indicated times. $\boldsymbol{D}, \chi^{2}=3, p<0.05$ (Log-Rank; Mantel-Cox Test). $\boldsymbol{E}, \chi^{2}=5, p<0.05$ (Log-Rank; Mantel-Cox Test).

\section{SC ablation had no effect on aneural AChR clusters but} abolished innervation and induced clusters

To investigate the function of SCs, we explored the consequences of ablating SCs during NMJ development. $P l p$-Cre ${ }^{\text {erT2 }}$ mice were crossed with Rosa26- diphtheria toxin Type A (DTA) mice, which express attenuated DTA upon Cre-mediated excision of transcription stop signal (Ivanova et al., 2005), to generate Plp-DTA mice (Fig. $3 A$ ). As shown in Figure 2A, TMX treatment at E8.5 caused Cre-mediated recombination in SC progenitor cells at E9.5. tdTomato was detected in most, if not all, $\mathrm{S} 100 \beta$-positive cells at P0 (Fig. $2 C$ ). Indeed, TMX treatment of $P l p$-DTA mice led to complete loss of S100 $\beta$-positive cells of E13.5 diaphragms (Figs. 3B, 4). Pregnant dams were not positive for both genotypes and thus not vulnerable to the toxic effect of DTA. However, in mice that were positive for both genotypes, axonal SCs and TSCs were reduced at embryonic and postnatal stages after TMX treatment (Fig. $3 B, C$ ). Axonal SCs were more resistant to DTA, compared with TSCs in adult animals (Fig. 3C). When treated with TMX at E16.5, neonatal Plp-DTA pups started dying $2 \mathrm{~d}$ after birth; most died before P4 (Fig. $3 D ; n=4$ ). Adult Plp-DTA mice 
A

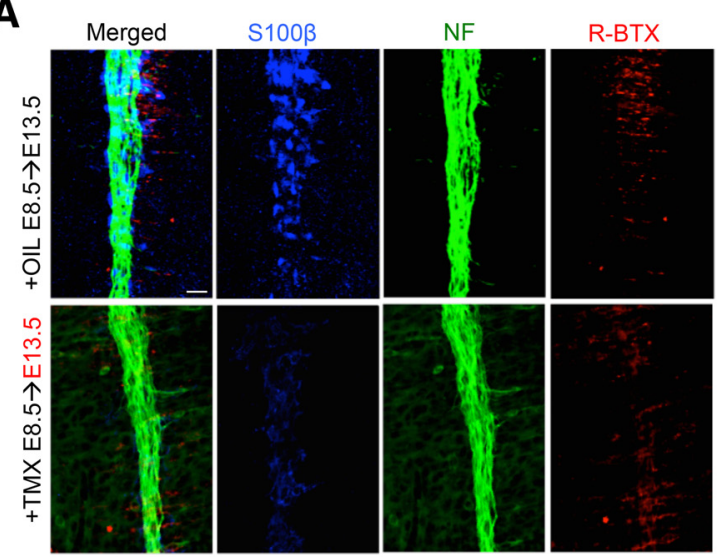

B
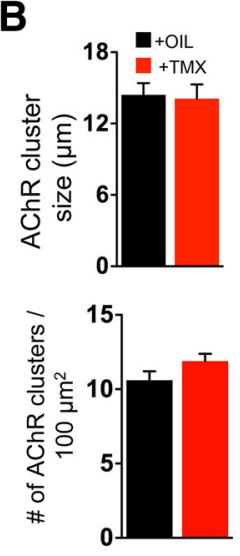

C

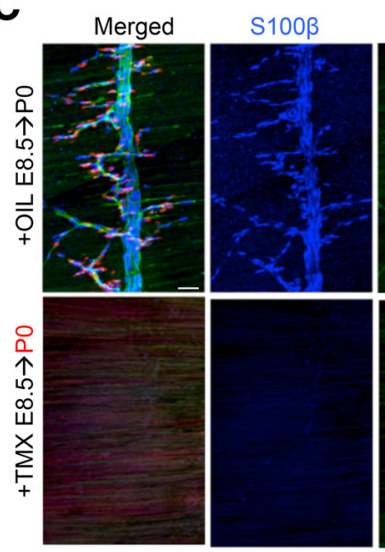

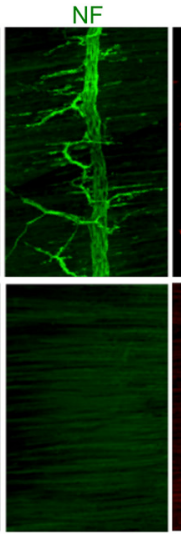

R-BTX

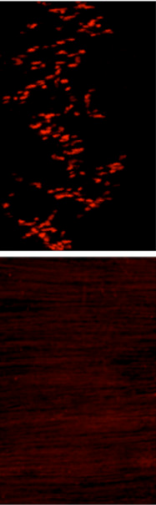

Figure 4. Little effect of SC ablation on aneural AChR clusters. $\boldsymbol{A}-\boldsymbol{C}$, Pregnant PIp-DTA mice were administered with TMX at E8.5. Embryos of indicated genotypes were analyzed at E13.5 (A, $\boldsymbol{B})$ and PO (C). Muscles were stained whole mount with NF antibody to label nerves, $S 100 \beta$ (blue) antibody to label SCS, and R-BTX (red) to label AChRs. SC ablation was demonstrated by loss of S100 $\beta$ in TMX-treated PIp-DTA mice. NMJs disappeared in the absence of SCS (C). $\boldsymbol{B}$, No change in aneural AChR clusters. Data are mean \pm SEM. $n=4$ embryos per group. Scale bar, $100 \mu m$.

started dying $3 \mathrm{~d}$ after TMX treatment (at P30) and most died within $15 \mathrm{~d}$ (Fig. $2 E ; n=9$ ).

Because SCs were in contact with aneural clusters (Fig. 1), we determined whether SCs were necessary for these clusters. Plp-DTA mice were treated with TMX at E8.5 and examined at E13.5. As shown in Figure 4, $A$ and $B$, similar aneural clusters, both in number and size, were observed in TMX-treated Plp-DTA mice, compared with vehicle controls, suggesting that aneural AChR cluster formation and maintenance do not require SCs. Axons retract in mice lacking neuregulin1, ErbB2, or ErbB3; consequently, NMJ formation is impaired (Riethmacher et al., 1997; Woldeyesus et al., 1999; Lin et al., 2000; Jaworski and Burden, 2006). This was thought to result from aberrant SC development. Interestingly, axons were missing in P0 Plp-DTA mice when SCs were ablated at E8.5 (Figs. $4 C, 5 A$ ), providing evidence for the dependence of motoneurons on SCs. Due to lack of axons, induced AChR clusters were completely abolished in P0 muscles (Fig. 4C).

\section{SC regulation of postsynaptic differentiation}

To study the effect of SCs on NMJ development, we induced DTA expression at different times during development and examined NMJs at P0. Two time points were chosen. One was E12.5, a time before muscle innervations, whereas the other was E16.5 when a majority of AChR clusters were innervated (Lin et al., 2001; Lin et al., 2008). When pregnant $P l p$-DTA mice were treated with TMX at E12.5, phrenic nerve branches were missing in muscles of $\mathrm{P} 0$ pups (Fig. 5A). Because nerve branches were present at E13.5 (Figs. 1, 4), their absence at P0 after SC ablation suggests that phrenic nerve branches could not be maintained without SCs and presumably retracted, in agreement with previous observations (Lin et al., 2000). Intriguingly, in the absence of SCs, the number of AChR clusters became fewer and smaller (Fig. 5A-C). Compared with controls, the size and density of AChR clusters were $\sim 40 \%$ and $\sim 10 \%$ smaller, respectively, in TMX-treated mice. Nevertheless, AChR clusters were located in the central region of muscle fibers (as in control mice) (Fig. 5A,C). These results suggest a role for SCs in regulating AChR cluster formation.

\section{SC regulation of postsynaptic maturation}

We attempted to ablate SCs after innervation by TMX treatment of pregnant mice at E15.5, 2-3 d after nerve arrival (Lin et al., 2000). As shown in Figure 5D-F, muscles of pups of TMX-treated mice displayed smaller AChR clusters. The cluster size in TMXtreated pups was $42.4 \pm 3.99 \mu \mathrm{m}^{2}$, compared with $65.0 \pm 1.16$ $\mu \mathrm{m}^{2}$ in controls $(n=10, p<0.001)$. However, the number of AChR clusters was similar to control, and each of the clusters appeared to be innervated. Moreover, AChR clusters were distributed in a central region, as observed in control mice (Fig. $5 D-F)$. We stained muscles with AlexaFluor-488-conjugated fasciculin II (FasII-488), a protein that binds the ACh hydrolyzing AChE (McMahan et al., 1978; Anglister et al., 1994; Bourne et al., 1995). Once made in skeletal muscles, AChE is secreted into the synaptic basal lamina; thus, fasciculin II is considered as a marker for synaptic basal lamina (Peng et al., 1999; Rotundo et al., 2008). As shown in Figure 6, $A$ and $B$, the size of FasII-488-stained clusters was reduced in TMX pups. Nevertheless, AChE staining was juxtaposed with that of R-BTX. Staining of synaptophysin, a marker of synaptic vesicles, was similar between pups of TMXand vehicle-treated mice (at E15.5) (Fig. 6C,D). These results of light microscopic studies suggest that SC ablation at E15.5 impairs postsynaptic maturation but has little effect on presynaptic differentiation. In support of this hypothesis were observations at the electron microscopic level. In both control and SC-ablated pups (at E15.5), nerve terminals were in contact with muscle fibers (Fig. 7A). The numbers of terminals per NMJ, synaptic vesicles, and active zones were similar between P0 pups of TMXadministered and control mice (at E15.5). No difference was observed in the synaptic cleft (Fig. 7B).

To further characterize the effect of SC ablation on NMJ formation, we recorded mEPPs, events that are produced by spontaneous release of $\mathrm{ACh}$ (Fig. $7 C, D$ ). The mEPP frequency, an indicator of vesicle release from presynaptic terminals, was similar between P0 pups of TMX-administered and control mice $(1.7 \pm 0.1$ and $1.98 \pm 0.13$, respectively) (at E15.5) (Fig. 7C,D), in agreement with morphologic data that presynaptic differentiation was not altered by SC ablation at E15.5. However, mEPP amplitude, which indicates AChR density on postsynaptic membrane, was reduced (Fig. 7C,D) from $2.3 \pm 0.1 \mathrm{mV}$ to $1.3 \mathrm{mV}$. Together, these morphologic and function studies suggest a role for SCs in postsynaptic differentiation.

\section{NMJ maintenance by SCs}

Next, we assessed the function of SCs at mature NMJs by ablating SCs in adult mice. Plp-DTA mice were treated with TMX at age of P30, a time when NMJs are mature (Balice-Gordon, 1997). TMX- 
A
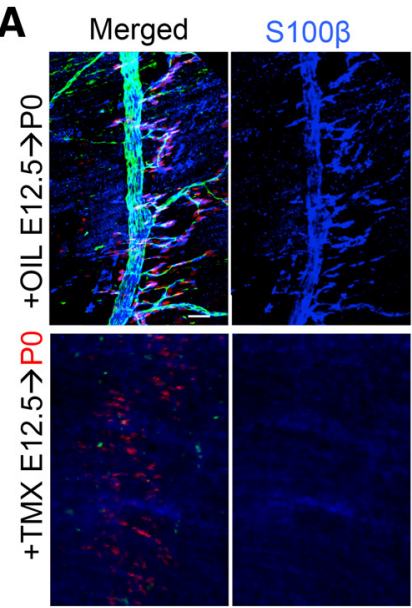

D Merged
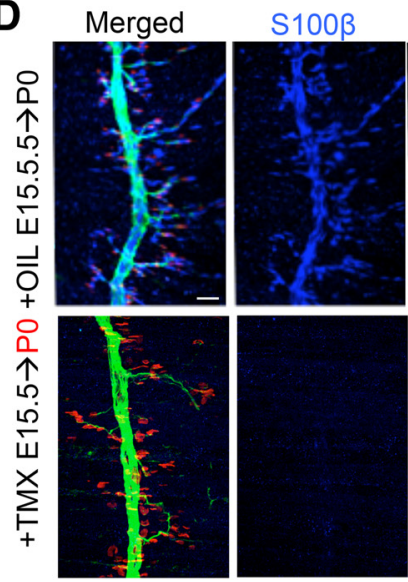

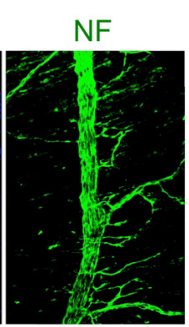

R-BTX
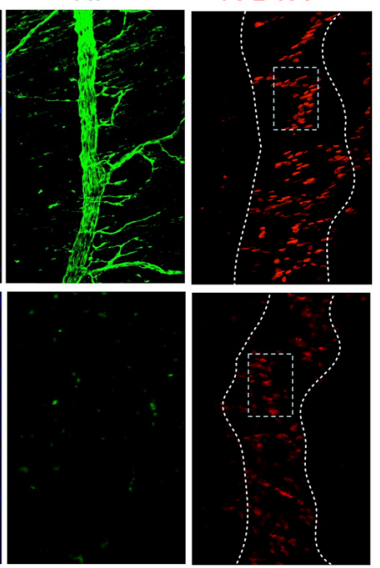

\begin{abstract}
NF
\end{abstract}

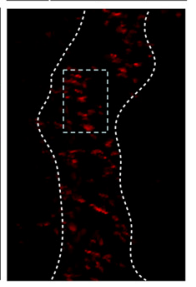

B
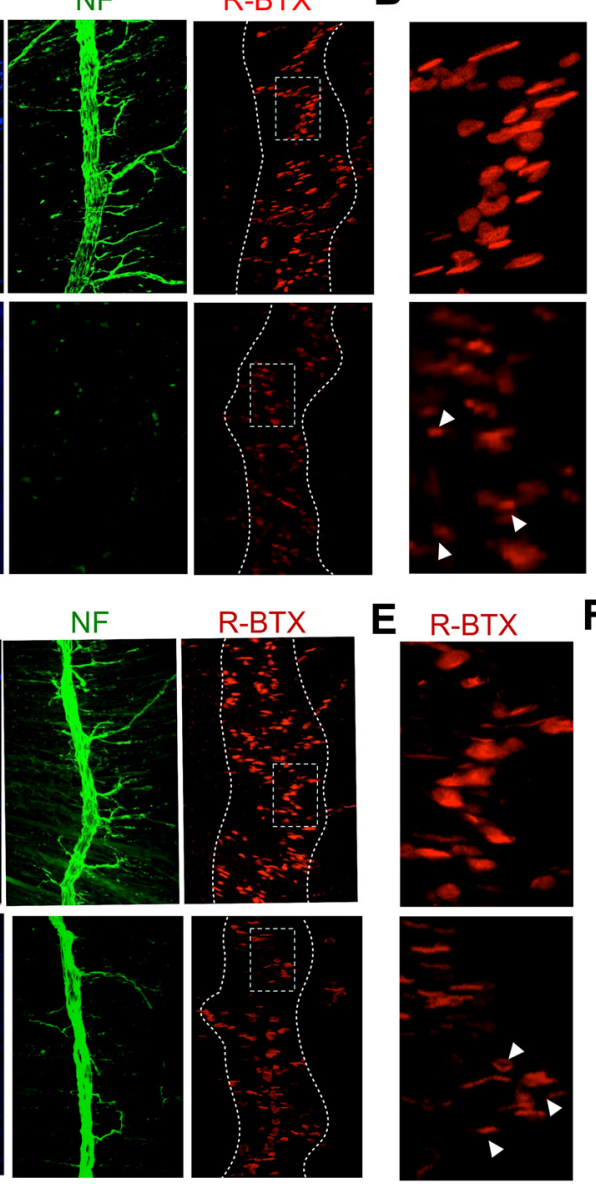

C
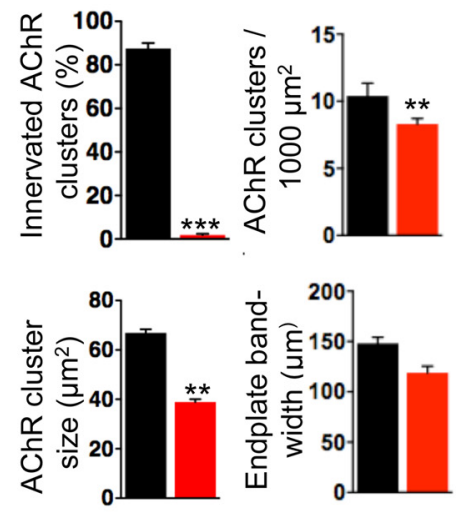

Figure 5. Impaired postsynaptic differentiation in TMX-treated PIp-DTA mice. $\boldsymbol{A}, \boldsymbol{D}$, PIp-DTA mice were administered with TMX at E12.5 (A) and E15.5 (D) to study the roles of SCs in NMJ development at different stages. Muscles were stained with NF antibody to label nerves, $S 100 \beta$ (blue) antibody to label SCs, and R-BTX (red) to label AChRs. $\boldsymbol{B}$, Enlarged image of the boxed area in $\boldsymbol{A}$. Arrowheads indicate relatively smaller AChR clusters. $\boldsymbol{C}$, Number and size of AChR clusters were reduced. $\boldsymbol{E}$, Enlarged image of the boxed area in $\boldsymbol{D}$. Arrowheads indicate relatively smaller AChR clusters. $\boldsymbol{F}$, Size of AChR clusters was smaller. Data are mean \pm SEM. ${ }^{* * *} p<0.0001$ (Student's $t$ test). ${ }^{* *} p<0.001$ (Student's $t$ test). $n=6$ embryos per group. Scale bar, $100 \mu \mathrm{m}$.

A

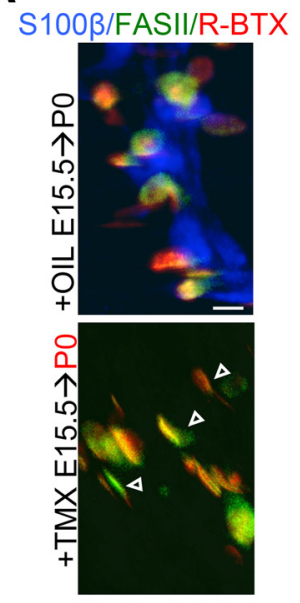

B
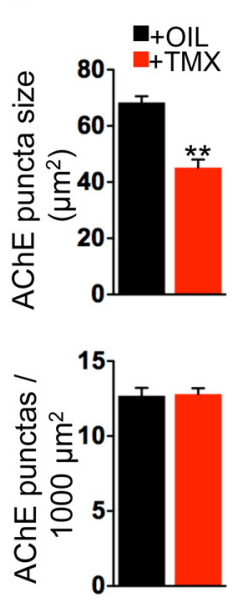

C
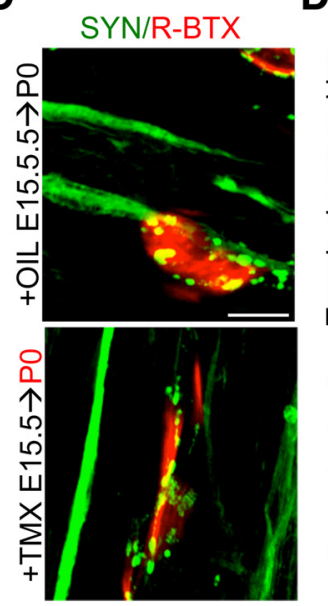

D
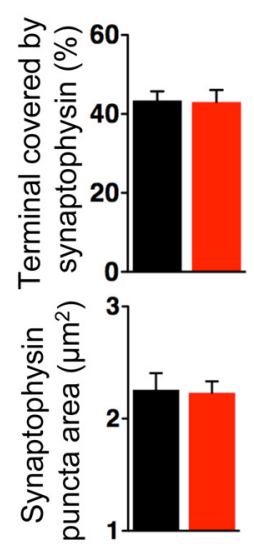

Figure 6. Impaired AChE staining in TMX-treated PIp-DTA mice. $\boldsymbol{A}, \boldsymbol{C}$, Pregnant, PIp-DTA were administered TMX at E15.5. Muscles were stained with fasciculin II in green (FASII) to label $A C h E(\boldsymbol{A})$, a marker for extracellular matrix. $\boldsymbol{A}, \mathrm{S} 100 \beta$ (blue) antibody to label SCS, synaptophysin (SYN) antibody to label synaptic vesicles (C), or R-BTX (red). $\boldsymbol{B}$, Extracellular matrix labeled by AChE is smaller in TMX-treated PIp-DTA. D, SYN is not altered in TMX-treated PIp-DTA mice. Data are mean \pm SEM. ${ }^{* *} p<0.001$ (Student's $t$ test). $n=6$ embryos per group. Scale bar, $10 \mu \mathrm{m}$.

treated mice began to die $3 \mathrm{~d}$ after treatment and some could survive to $7 \mathrm{~d}$ (Fig. 3E). To identify a window of NMJ characterization, we determined when TSCs were altered. As shown in Figure 3, S100 $\beta$ staining associated with axon terminals was almost diminished $3 \mathrm{~d}$ after TMX treatment; however, S100 $\beta$ staining associated with axons remained at $80 \%$ of control value, suggesting that TSCs were more sensitive to DTA, compared with axonal SCs. Therefore, we focused on mice $3 \mathrm{~d}$ after TMX treatment when TSCs were most ablated while a majority of axonal SCs remained. To determine whether SC ablation altered NMJ function, we characterized CMAPs in the gastrocnemius muscles in response to needle electrode stimulations (Shen et al., 2013; Barik et al., 2014b). In control (oil-treated) Plp-DTA mice, CMAPs did not significantly differ over 10 consecutive stimuli delivered at 20 or $40 \mathrm{~Hz}$ (Fig. 8). In contrast, there was a significant reduction in CMAPs over 10 consecutive stimuli in TMX-treated mice. 
A

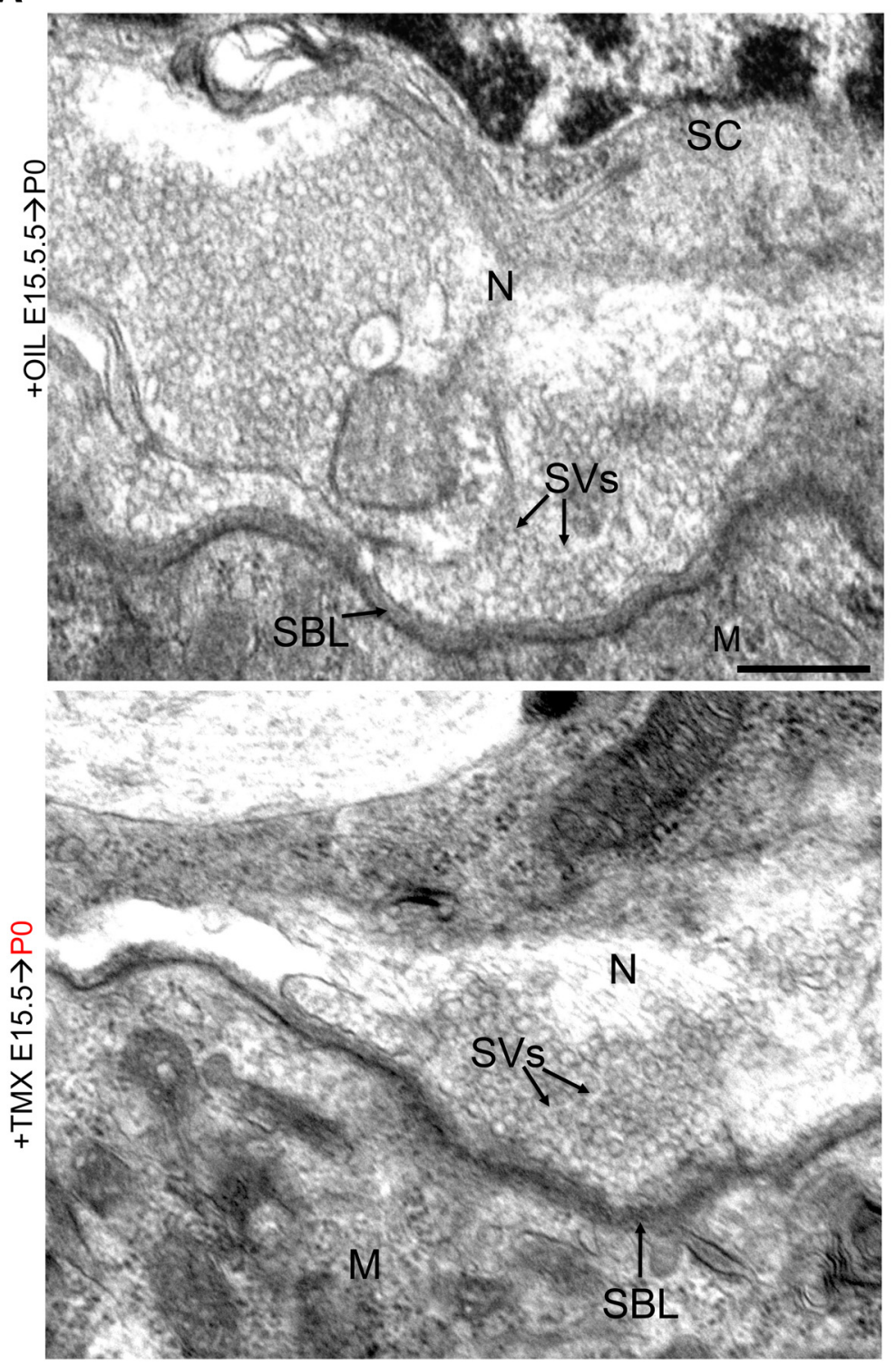

B
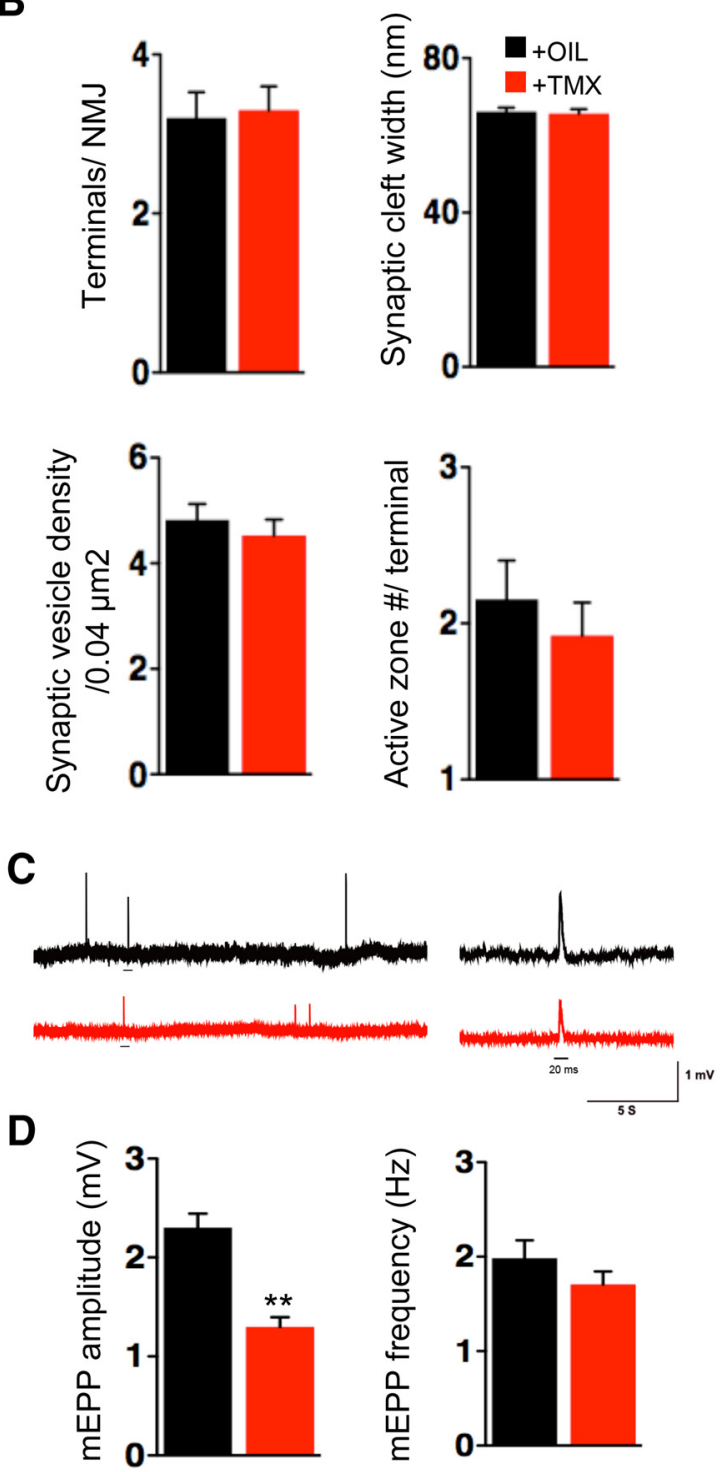

Figure 7. Postsynaptic NMJ defects in TMX-treated PIp-DTA mice. A, TMX or oil was administered at E15.5 in pregnant mice, and electron micrographs of NMJs from diaphragm muscle of P0 mice were analyzed. $\boldsymbol{B}$, Ultrastructural properties of NMJs were unaltered in PIp-DTA mice. $\boldsymbol{C}$, Representative traces of mEPPs recorded from P0 diaphragms. $\boldsymbol{D}$, mEPP amplitudes were reduced in TMX-treated PIp-DTA mice. Data are mean \pm SEM. ${ }^{* *} p<0.001$ (Student's $t$ test). $n=6$ pups per group. Scale bar, $500 \mathrm{~nm}$.

The reduction was significant after the fifth stimulus at $20 \mathrm{~Hz}$ and after fourth at $40 \mathrm{~Hz}$ (Fig. $8 B$ ). The 10th CMAP was reduced by $\sim 15 \%$ compared with the first CMAP $(99.91 \pm 1.04 \%$ and $83.92 \pm$ $5.09 \%, n=5, p<0.05$ at $20 \mathrm{~Hz}$ and $96.95 \pm 1.42 \%$ and $79.20 \pm$ $4.97 \%, n=5, p<0.05$ at $40 \mathrm{~Hz}$ ) (Fig. $8 B$ ). The frequency-dependent reduction of CMAP suggested that there was a progressive loss of successful transmission after repeated stimulations (Fig. 8C).

To understand underlying cellular mechanisms, muscles were stained with R-BTX and antibodies against NF/SYN and $S 100 \beta$. As shown in Figure 9, $A$ and $B$, NMJs of TMX-treated mice did not show noticeable difference in morphology $3 \mathrm{~d}$ after TMX treatment. At this time, nerve terminals were in complete registration with AChR clusters. Remarkably, mEPP amplitudes were reduced, whereas mEPP frequencies were not altered (Fig. 10A,B), suggesting impaired postsynaptic function, but not presynaptic function at this time. At $6 \mathrm{~d}$ after TMX treatment, however, both mEPP frequency and amplitude were reduced in TMX-treated muscles, compared with control (Fig. 10A,B), suggesting possible NMJ failure. Accordingly, AChR clusters became fragmented $6 \mathrm{~d}$ after TMX treatment, which was associated with a reduction in NMJ size. Nerves in Figure $9 A$ were revealed by staining with a combination of antibodies against SYN and NF, which label synaptic vesicles (i.e., nerve terminals) and axons (i.e., nerve branches). To determine whether nerve terminals were altered in muscles after TMX treatment, we stained muscles only with anti-SYN antibodies. As shown in Figure 9, $C$ and $D$, SYN staining was reduced in muscles of TMX-treated mice for $6 \mathrm{~d}$ by $\sim 25 \%(89.9 \pm 2.9$ and $68.0 \pm 3.0$ for 3 and $6 \mathrm{~d}$, respectively; $n=$ $4, p<0.001$ ), but not for $3 \mathrm{~d}$. These results suggest that, in the absence of SCs, NMJ disintegration occurs first on the postsynaptic side and then presynaptic side.

\section{Discussion}

We characterized NMJs after genetically ablating SCs during development and in adulthood. The major findings of this paper are as 
A
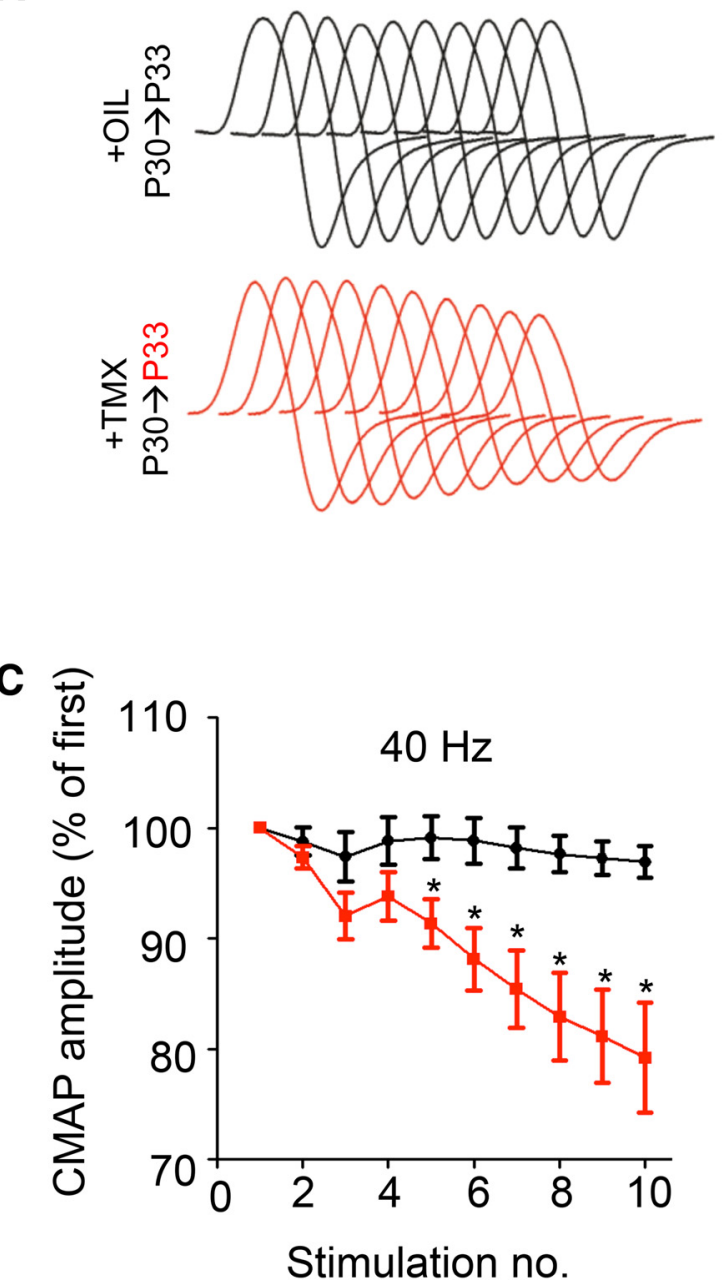

B

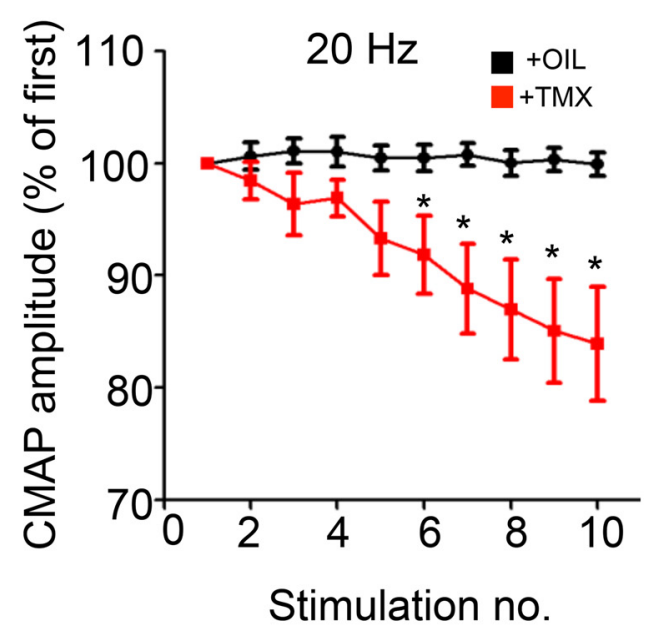

D

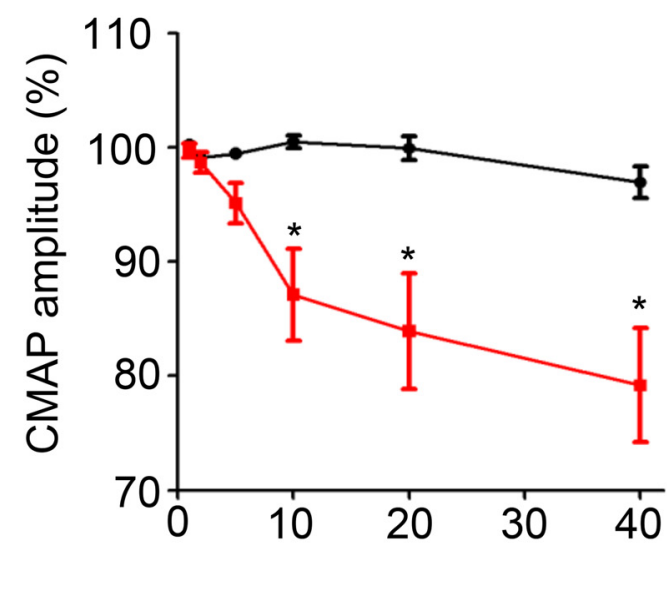

Figure 8. CMAP reduction in TMX-treated PIp-DTA mice. CMAPs were recorded from the gastrocnemius in response to a train of 10 submaximal stimuli at different frequencies. The first stimulus response in control mice was assigned 100\%. A, Representative CMAP traces. $\boldsymbol{B}$, Reduced CMAP amplitudes at $20 \mathrm{~Hz}$. C, Reduced CMAP amplitudes at $40 \mathrm{~Hz}$. D, CMAP amplitudes of the 10th stimulation at different stimulation frequencies. Data are mean \pm SEM. ${ }^{*} p<0.05$ (Student's $t$ test). $n=4$ mice per group.

follows. First, SCs led nerve terminals to prepatterned AChRs. However, ablating SCs at E8.5 (i.e., prior nerve arrival to the clusters) had little effect on aneural AChR clusters at E13.5, suggesting that SCs may not be necessary for aneural clusters. Second, SC ablation at E12.5, a time when phrenic nerves were approaching muscle fibers, resulted in smaller and fewer nerve-induced AChR clusters; however, SC ablation at E15.5 reduced AChR cluster size but had no effect on cluster density, suggesting that SCs are involved in AChR cluster maturation. mEPP amplitude, but not frequency, was reduced when SCs were ablated at E15.5, suggesting that postsynaptic alterations may occur ahead of presynaptic deficits. Third, ablation of SCs at P30, after NMJ maturation, led to NMJ fragmentation and neuromuscular transmission deficits. $\mathrm{mEPP}$ amplitude was reduced $3 \mathrm{~d}$ after SC ablation, but both amplitude and frequency were reduced $6 \mathrm{~d}$ after. Together, these results indicate that SCs are not only required for NMJ formation but also necessary for its maintenance; and postsynaptic function and structure appeared to be more sensitive to SC ablation.

We observed that SCs were ahead of nerve terminals and in contact with more aneural AChRs than nerve terminals, suggesting that SCs may lead nerve terminals to targets during NMJ formation. This observation seemed to deviate from the idea that nerve terminals interact with targets before the arrival of glial cells
(Tessier-Lavigne and Goodman, 1996). In developing insects, glial cells were found to provide guidance to growing axons (Bastiani and Goodman, 1986; Sepp et al., 2001; Aigouy et al., 2004). Ablation of peripheral glia in Drosophila impairs migration of both sensory and motoneurons (Sepp et al., 2001). In zebrafish, however, glial cells seem to follow axon terminals to migrate (Gilmour et al., 2002). Although in mouse NMJ, SCs appear to migrate in advance of nerve terminals, further investigation is necessary to determine whether they are critical for axon pathfinding or synaptogenesis.

The role of SCs in NMJ development was inferred by studies of mutant mice lacking neuregulin 1 signaling. In mutant mice without ErbB2, for example, SCs are missing; motor nerves can project to muscle fibers. However, nerve terminals are poorly fasciculated, disorganized, or retracted before E15 after initial contact with muscle fibers (Lin et al., 2000). Moreover, mutant mice die in embryonic stages because of abnormal development of vital organs, such as the heart (Riethmacher et al., 1997; Morris et al., 1999; Woldeyesus et al., 1999). Consequently, exactly how SCs regulate NMJ formation remained unknown. By using a TMX-inducible expression system, we ablated SCs at three different stages: during initial interaction between nerve terminals and muscle fibers, during NMJ development, and after NMJ matura- 
A
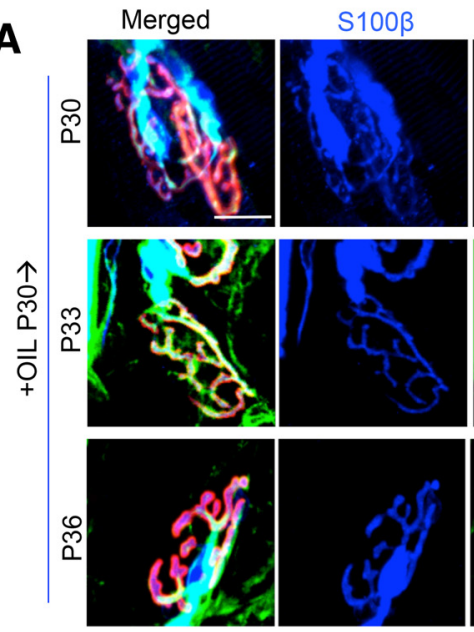

B

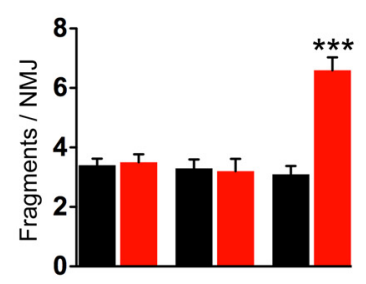

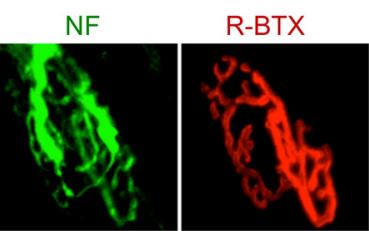
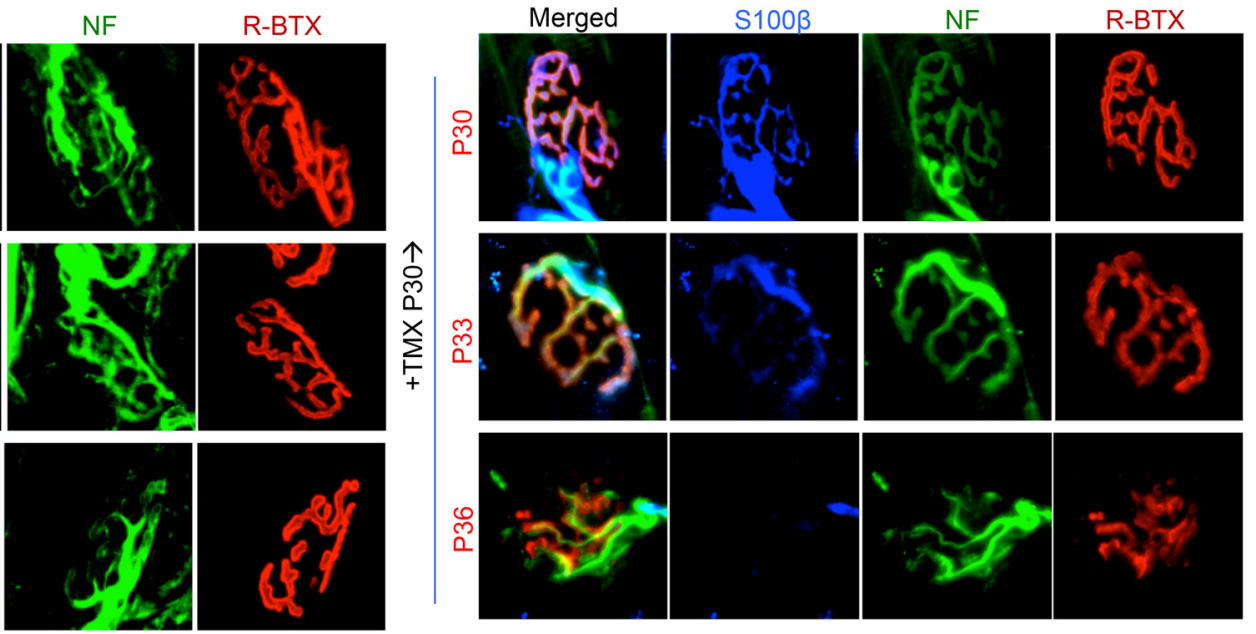

C

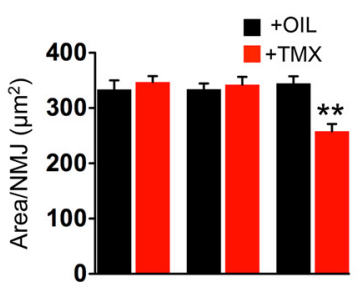

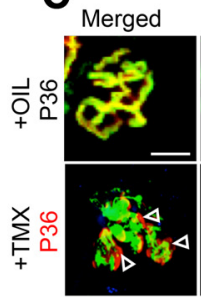

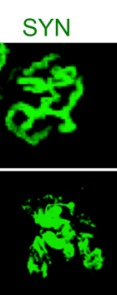
R-BTX

D

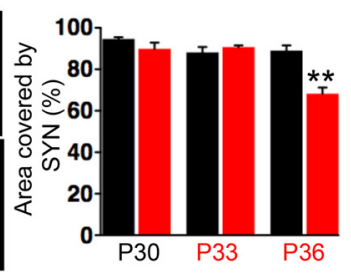

Figure 9. Dependence of NMJ maintenance on SCs. A, NMJ fragmentation in the absence of SCs. TMX or oil was administered at P30, and TA muscles were harvested in 3 or $6 \mathrm{~d}$ and stained with NF and SYN antibodies to label nerves, $S 100 \beta$ (blue) antibody to label SCS, and R-BTX (red) to label AChRs. B, Quantification of data in $A$ shows extensive fragmentation 6 d after TMX administration. C, Reduced synaptophysin staining in muscles $6 \mathrm{~d}$ after TMX treatment. Muscles were stained with SYN antibody to label synaptic vesicles and R-BTX (red). Solid arrowheads indicate reduced SYN levels and fragmented AChR clusters. D, Quantification of data in C. Data are mean \pm SEM. ${ }^{* * *} p<0.0001$ (Student's $t$ test). ${ }^{* *} p<0.001$ (Student's $t$ test). $n=4$ mice per group. Scale bar, $10 \mu$ m.

A
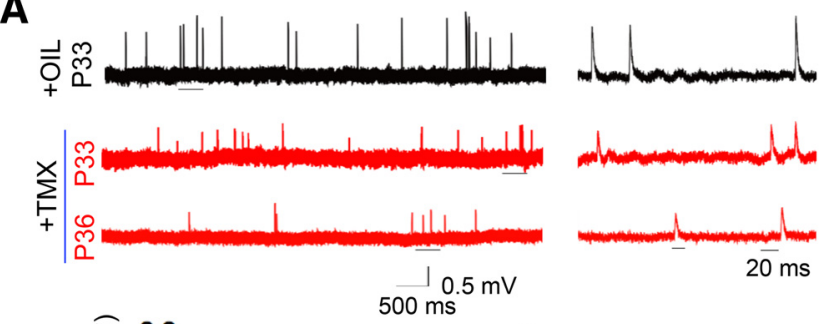

B
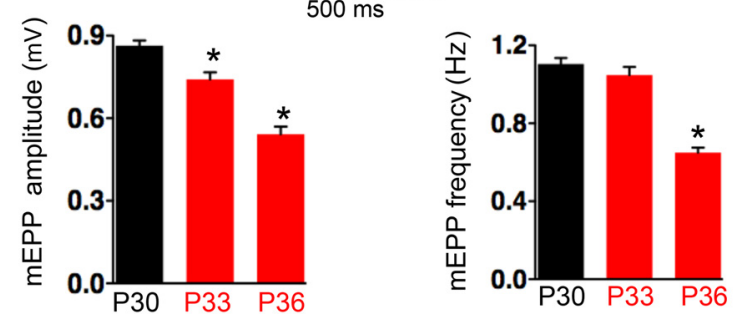

Figure 10. Electrophysiological deficits at adult NMJs in the absence of SCS. $\boldsymbol{A}$, Reduced $\mathrm{mEPP}$ amplitudes occurred ahead of frequency reduction. Diaphragms were recorded 3 and $6 \mathrm{~d}$ after TMX or oil administration of P30 mice. $\boldsymbol{B}$, Quantification of data. Data are mean \pm SEM. ${ }^{*} p<0.05$ (Student's $t$ test). $n=4$ mice per group.

tion. We were able to infer the role of SCs on presynaptic and postsynaptic development. When SCs were ablated during development, the size of AChR clusters was reduced (Fig. 4) and concomitantly, mEPP amplitude was suppressed (Fig. 5), suggestive of postsynaptic deficits in the absence of SCs. In contrast, however, mEPP frequency, an indicator of spontaneous vesicle release, was not altered by SC ablation. In accord, the number of vesicles was similar between TMX-treated and control embryos. Apparently, AChR clusters persist in the absence of SCs and ax- ons (Fig. 5). Perhaps, this may be due to residual neuronal agrin deposited in the synaptic basal lamina by nerve terminals and diminished muscle activity that is known to disrupt NMJs (Misgeld et al., 2002; Brandon et al., 2003). How SCs regulate postsynaptic differentiation and maintenance remains unknown. Several studies indicate that SCs may promote synaptogenesis by releasing synaptogenic factors or indirectly by regulating motoneurons. Conditioned medium of frog SCs enhance AChR clustering in cultured myotubes (Peng et al., 2003). Frog spinal motoneurons form fewer synapses in the absence of SCs, compared with neurons cocultured with SCs (Ullian et al., 2004). Although the identity of SC-derived factors is unclear, there were a few candidates. SCs may release Agrin, a factor known to directly induce AChR clusters on muscle cells (Yang et al., 2001). Agrin of SCs was implicated in target selection and synapse formation by regenerated axons (Yang et al., 2001). SCs may release TGF $\beta$, which enhances synapse formation in cultured systems (Feng and KO, 2008b). Glial-cell-derived TGF $\beta$ was shown to positively regulate NMJ formation (Fuentes-Medel et al., 2012; Kerr et al., 2014), possibly by increasing Agrin gene expression in motoneurons via TGF $\beta$ signaling at motoneuron terminals and somas (Krieglstein et al., 1998). Recently, Wnt ligands were shown to be involved in postsynaptic differentiation (Packard et al., 2002; Henriquez et al., 2008; Koles and Budnik, 2012; Strochlic et al., 2012; Zhang et al., 2012; Barik et al., 2014a; Messéant et al., 2015). Wnts are expressed in glia (Castelo-Branco et al., 2006; Kerr et al., 2014) and are important in clustering postsynaptic receptors on muscles in Drosophila (Kerr et al., 2014). Similar functions for glial cells have been implicated in the CNS as astrocytes were able to increase the number of synapses when cultured with neurons and were critical for the maintenance of 
these synapses (Ullian et al., 2001, 2004). By ablating perisynaptic SCs in frog via complement-mediated cell lysis, a previous study indicated that perisynaptic SC loss causes nerve terminal retraction, impairs presynaptic structure and function (such as reduced mEPP frequency), and reduces muscle strength (Reddy et al., 2003). However, postsynaptic morphology and mEPP amplitude were not changed. These observations suggest that, in frog, perisynaptic SCs are necessary for maintaining presynaptic structure and function at mature NMJs (Reddy et al., 2003). In mice, ablation of TSCs by anti-disialoside antibodies from patients with autoimmune neuropathy damaged both structure and function of the NMJ (Halstead et al., 2004). Intriguingly, in adult mice, SC ablation initially caused postsynaptic deficits, which were followed by presynaptic changes. For example, $3 \mathrm{~d}$ after SC ablation, only mEPP amplitude was reduced, whereas mEPP frequency and synaptophysin staining were not changed. Our results suggest that postsynaptic dysfunction may be an initial event of NMJ disintegration after SC ablation in mice. Within $6 \mathrm{~d}$ of SC ablation, however, both postsynaptic and presynaptic deficits were observed. Because Cre expression in $P l p-C_{r e E R}{ }^{\mathrm{T} 2}$ mice is not specific for perisynaptic SCs (Doerflinger et al., 2003), interpretation of the presynaptic deficits deserves caution. Moreover, TMX induction in Plp-DTA mice might have caused ablation of myelinating SCs. Myelinating SCs have been implicated in synaptic remodeling (Roche et al., 2014). Dysmyelinated motoneurons cause defects in NMJ maintenance in mice (Yin et al., 2004). We are unable to determine at this time whether the late-onset presynaptic deficits were due to loss of myelinating SCs or as a consequence of NMJ disintegration.

An unanswered question is whether TSCs are necessary for synapse elimination, a critical aspect of NMJ maturation. During this process, motoneurons compete with each other to establish the most efficient connection (Walsh and Lichtman, 2003; Turney and Lichtman, 2012). Axons of eliminated synapses retract in bulb-like structures, which are engulfed by TSCs (Riley, 1981; Bishop et al., 2004). This process is promoted by Type III Nrg1 expressed on motoneuron surface, which stimulates TSCs (Lee et al., 2016). TCSs remove and eliminate branches of nerve terminals in contact with postsynaptic receptors (Smith et al., 2013), form retraction bulbs, and shed remnants of axons or axosomes (Bishop et al., 2004). They do not select or determine which synapses are to be eliminated (Smith et al., 2013). TSCs might also sense ACh and ATP from nerves and in turn influence neurotransmitter release at the NMJ (Jahromi et al., 1992; Robitaille, 1998). Selective ablation of SCs particularly TSCs by genetic manipulations, such as used in this study, will be fruitful in delineating their roles in synaptic elimination.

\section{References}

Aigouy B, Van de Bor V, Boeglin M, Giangrande A (2004) Time-lapse and cell ablation reveal the role of cell interactions in fly glia migration and proliferation. Development 131:5127-5138. CrossRef Medline

Anglister L, Stiles JR, Salpeter MM (1994) Acetylcholinesterase density and turnover number at frog neuromuscular junctions, with modeling of their role in synaptic function. Neuron 12:783-794. CrossRef Medline

Avila OL, Drachman DB, Pestronk A (1989) Neurotransmission regulates stability of acetylcholine receptors at the neuromuscular junction. J Neurosci 9:2902-2906. Medline

Balice-Gordon RJ (1997) Age-related changes in neuromuscular innervation. Muscle Nerve Suppl 5:S83-S87. Medline

Barik A, Zhang B, Sohal GS, Xiong WC, Mei L (2014a) Crosstalk between Agrin and Wnt signaling pathways in development of vertebrate neuromuscular junction. Dev Neurobiol 74:828-838. CrossRef Medline

Barik A, Lu Y, Sathyamurthy A, Bowman A, Shen C, Li L, Xiong WC, Mei L (2014b) LRP4 is critical for neuromuscular junction maintenance. J Neurosci 34:13892-13905. CrossRef Medline

Bastiani MJ, Goodman CS (1986) Guidance of neuronal growth cones in the grasshopper embryo: III. Recognition of specific glial pathways. J Neurosci 6:3542-3551. Medline

Bean JC, Lin TW, Sathyamurthy A, Liu F, Yin DM, Xiong WC, Mei L (2014) Genetic labeling reveals novel cellular targets of schizophrenia susceptibility gene: distribution of GABA and non-GABA ErbB4-positive cells in adult mouse brain. J Neurosci 34:13549-13566. CrossRef Medline

Bishop DL, Misgeld T, Walsh MK, Gan WB, Lichtman JW (2004) Axon branch removal at developing synapses by axosome shedding. Neuron 44:651-661. CrossRef Medline

Bourne Y, Taylor P, Marchot P (1995) Acetylcholinesterase inhibition by fasciculin: crystal structure of the complex. Cell 83:503-512. CrossRef Medline

Brandon EP, Lin W, D'Amour KA, Pizzo DP, Dominguez B, Sugiura Y, Thode S, Ko CP, Thal LJ, Gage FH, Lee KF (2003) Aberrant patterning of neuromuscular synapses in choline acetyltransferase-deficient mice. J Neurosci 23:539-549. Medline

Brill MS, Lichtman JW, Thompson W, Zuo Y, Misgeld T (2011) Spatial constraints dictate glial territories at murine neuromuscular junctions. J Cell Biol 195:293-305.

Castelo-Branco G, Sousa KM, Bryja V, Pinto L, Wagner J, Arenas E (2006) Ventral midbrain glia express region-specific transcription factors and regulate dopaminergic neurogenesis through Wnt-5a secretion. Mol Cell Neurosci 31:251-262. CrossRef Medline

Darabid H, Arbour D, Robitaille R (2013) Glial cells decipher synaptic competition at the mammalian neuromuscular junction. J Neurosci 33: 1297-1313. CrossRef Medline

Doerflinger NH, Macklin WB, Popko B (2003) Inducible site-specific recombination in myelinating cells. Genesis 35:63-72. CrossRef Medline

Engel AG, Ohno K, Sine SM (2003) Sleuthing molecular targets for neurological diseases at the neuromuscular junction. Nat Rev Neurosci 4: 339-352. CrossRef Medline

Feng Z, Ko CP (2008a) Schwann cells promote synaptogenesis at the neuromuscular junction via transforming growth factor-betal. J Neurosci 28:9599-9609. CrossRef Medline

Feng Z, Ko CP (2008b) The role of glial cells in the formation and maintenance of the neuromuscular junction. Ann N Y Acad Sci 1132:19-28. CrossRef Medline

Flanagan-Steet H, Fox MA, Meyer D, Sanes JR (2005) Neuromuscular synapses can form in vivo by incorporation of initially aneural postsynaptic specializations. Development 132:4471-4481. CrossRef Medline

Fox MA, Sanes JR, Borza DB, Eswarakumar VP, Fässler R, Hudson BG, John SW, Ninomiya Y, Pedchenko V, Pfaff SL, Rheault MN, Sado Y, Segal Y, Werle MJ, Umemori H (2007) Distinct target-derived signals organize formation, maturation, and maintenance of motor nerve terminals. Cell 129:179-193. CrossRef Medline

Fuentes-Medel Y, Ashley J, Barria R, Maloney R, Freeman M, Budnik V (2012) Integration of a retrograde signal during synapse formation by glia-secreted TGFbeta ligand. Curr Biol 22:1831-1838. CrossRef Medline

Gilmour DT, Maischein HM, Nüsslein-Volhard C (2002) Migration and function of a glial subtype in the vertebrate peripheral nervous system. Neuron 34:577-588. CrossRef Medline

Godfrey EW, Nitkin RM, Wallace BG, Rubin LL, McMahan UJ (1984) Components of Torpedo electric organ and muscle that cause aggregation of acetylcholine receptors on cultured muscle cells. J Cell Biol 99: 615-627. CrossRef Medline

Griffin JW, Thompson WJ (2008) Biology and pathology of nonmyelinating Schwann cells. Glia 56:1518-1531. CrossRef Medline

Halstead SK, O'Hanlon GM, Humphreys PD, Morrison DB, Morgan BP, Todd AJ, Plomp JJ, Willison HJ (2004) Anti-disialoside antibodies kill perisynaptic Schwann cells and damage motor nerve terminals via membrane attack complex in a murine model of neuropathy. Brain 127: 2109-2123. CrossRef Medline

Henriquez JP, Webb A, Bence M, Bildsoe H, Sahores M, Hughes SM, Salinas PC (2008) Wnt signaling promotes AChR aggregation at the neuromuscular synapse in collaboration with agrin. Proc Natl Acad Sci U S A 105: 18812-18817. CrossRef Medline

Huh WJ, Mysorekar IU, Mills JC (2010) Inducible activation of Cre recombinase in adult mice causes gastric epithelial atrophy, metaplasia, and 
regenerative changes in the absence of "floxed" alleles. Am J Physiol Gastrointest Liver 299:G368-G380. CrossRef Medline

Ivanova A, Signore M, Caro N, Greene ND, Copp AJ, Martinez-Barbera JP (2005) In vivo genetic ablation by Cre-mediated expression of diphtheria toxin fragment A. Genesis 43:129-135. CrossRef Medline

Jahromi BS, Robitaille R, Charlton MP (1992) Transmitter release increases intracellular calcium in perisynaptic Schwann cells in situ. Neuron 8:1069-1077. CrossRef Medline

Jaworski A, Burden SJ (2006) Neuromuscular synapse formation in mice lacking motor neuron- and skeletal muscle-derived Neuregulin-1. J Neurosci 26:655-661. CrossRef Medline

Jessen KR, Mirsky R (2005) The origin and development of glial cells in peripheral nerves. Nat Rev Neurosci 6:671-682. CrossRef Medline

Jing L, Lefebvre JL, Gordon LR, Granato M (2009) Wnt signals organize synaptic prepattern and axon guidance through the zebrafish unplugged/ MuSK receptor. Neuron 61:721-733. CrossRef Medline

Kerr KS, Fuentes-Medel Y, Brewer C, Barria R, Ashley J, Abruzzi KC, Sheehan A, Tasdemir-Yilmaz OE, Freeman MR, Budnik V (2014) Glial wingless/ Wnt regulates glutamate receptor clustering and synaptic physiology at the Drosophila neuromuscular junction. J Neurosci 34:2910-2920. CrossRef Medline

Kim N, Burden SJ (2008) MuSK controls where motor axons grow and form synapses. Nat Neurosci 11:19-27. CrossRef Medline

Kim N, Stiegler AL, Cameron TO, Hallock PT, Gomez AM, Huang JH, Hubbard SR, Dustin ML, Burden SJ (2008) Lrp4 is a receptor for Agrin and forms a complex with MuSK. Cell 135:334-342. CrossRef Medline

Ko CP, Robitaille R (2015) Perisynaptic Schwann cells at the neuromuscular synapse: adaptable, multitasking glial cells. Cold Spring Harb Perspect Biol 7:a020503. CrossRef Medline

Koles K, Budnik V (2012) Wnt signaling in neuromuscular junction development. Cold Spring Harb Perspect Biol 4:a008045. CrossRef Medline

Krieglstein K, Henheik P, Farkas L, Jaszai J, Galter D, Krohn K, Unsicker K (1998) Glial cell line-derived neurotrophic factor requires transforming growth factor-beta for exerting its full neurotrophic potential on peripheral and CNS neurons. J Neurosci 18:9822-9834. Medline

Lee YI, Li Y, Mikesh M, Smith I, Nave KA, Schwab MH, Thompson WJ (2016) Neuregulin1 displayed on motor axons regulates terminal Schwann cellmediated synapse elimination at developing neuromuscular junctions. Proc Natl Acad Sci U S A 113:E479-E487. CrossRef Medline

Li XM, Dong XP, Luo SW, Zhang B, Lee DH, Ting AK, Neiswender H, Kim CH, Carpenter-Hyland E, Gao TM, Xiong WC, Mei L (2008) Retrograde regulation of motoneuron differentiation by muscle beta-catenin. Nat Neurosci 11:262-268. CrossRef Medline

Lin S, Landmann L, Ruegg MA, Brenner HR (2008) The role of nerve- versus muscle-derived factors in mammalian neuromuscular junction formation. J Neurosci 28:3333-3340. CrossRef Medline

Lin W, Sanchez HB, Deerinck T, Morris JK, Ellisman M, Lee KF (2000) Aberrant development of motor axons and neuromuscular synapses in erbB2-deficient mice. Proc Natl Acad Sci U S A 97:1299-1304. CrossRef Medline

Lin W, Burgess RW, Dominguez B, Pfaff SL, Sanes JR, Lee KF (2001) Distinct roles of nerve and muscle in postsynaptic differentiation of the neuromuscular synapse. Nature 410:1057-1064. CrossRef Medline

Liu Y, Sugiura Y, Wu F, Mi W, Taketo MM, Cannon S, Carroll T, Lin W (2012) beta-Catenin stabilization in skeletal muscles, but not in motor neurons, leads to aberrant motor innervation of the muscle during neuromuscular development in mice. Dev Biol 366:255-267. CrossRef Medline

Madisen L, Zwingman TA, Sunkin SM, Oh SW, Zariwala HA, Gu H, Ng LL, Palmiter RD, Hawrylycz MJ, Jones AR, Lein ES, Zeng H (2010) A robust and high-throughput Cre reporting and characterization system for the whole mouse brain. Nat Neurosci 13:133-140. CrossRef Medline

McMahan UJ (1990) The agrin hypothesis. Cold Spring Harbor Symp Quant Biol 55:407-418. CrossRef Medline

McMahan UJ, Sanes JR, Marshall LM (1978) Cholinesterase is associated with the basal lamina at the neuromuscular junction. Nature 271: 172-174. CrossRef Medline

Messéant J, Dobbertin A, Girard E, Delers P, Manuel M, Mangione F, Schmitt A, Le Denmat D, Molgó J, Zytnicki D, Schaeffer L, Legay C, Strochlic L (2015) MuSK frizzled-like domain is critical for mammalian neuromuscular junction formation and maintenance. J Neurosci 35:4926-4941. CrossRef Medline
Miniou P, Tiziano D, Frugier T, Roblot N, Le Meur M, Melki J (1999) Gene targeting restricted to mouse striated muscle lineage. Nucleic Acids Res 27:e27. CrossRef Medline

Misgeld T, Burgess RW, Lewis RM, Cunningham JM, Lichtman JW, Sanes JR (2002) Roles of neurotransmitter in synapse formation: development of neuromuscular junctions lacking choline acetyltransferase. Neuron 36: 635-648. CrossRef Medline

Morris JK, Lin W, Hauser C, Marchuk Y, Getman D, Lee KF (1999) Rescue of the cardiac defect in ErbB2 mutant mice reveals essential roles of ErbB2 in peripheral nervous system development. Neuron 23:273-283. CrossRef Medline

Nguyen QT, Sanes JR, Lichtman JW (2002) Pre-existing pathways promote precise projection patterns. Nat Neurosci 5:861-867. CrossRef Medline

Nitkin RM, Smith MA, Magill C, Fallon JR, Yao YM, Wallace BG, McMahan UJ (1987) Identification of agrin, a synaptic organizing protein from Torpedo electric organ. J Cell Biol 105:2471-2478. CrossRef Medline

O’Malley JP, Waran MT, Balice-Gordon RJ (1999) In vivo observations of terminal Schwann cells at normal, denervated, and reinnervated mouse neuromuscular junctions. J Neurobiol 38:270-286. CrossRef Medline

Packard M, Koo ES, Gorczyca M, Sharpe J, Cumberledge S, Budnik V (2002) The Drosophila Wnt, wingless, provides an essential signal for pre- and post-synaptic differentiation. Cell 111:319-330. CrossRef Medline

Peng HB, Xie H, Rossi SG, Rotundo RL (1999) Acetylcholinesterase clustering at the neuromuscular junction involves perlecan and dystroglycan. J Cell Biol 145:911-921. CrossRef Medline

Peng HB, Yang JF, Dai Z, Lee CW, Hung HW, Feng ZH, Ko CP (2003) Differential effects of neurotrophins and schwann cell-derived signals on neuronal survival/growth and synaptogenesis. J Neurosci 23:5050-5060. Medline

Reddy LV, Koirala S, Sugiura Y, Herrera AA, Ko CP (2003) Glial cells maintain synaptic structure and function and promote development of the neuromuscular junction in vivo. Neuron 40:563-580. CrossRef Medline

Reynolds ML, Woolf CJ (1992) Terminal Schwann cells elaborate extensive processes following denervation of the motor endplate. J Neurocytol 21: 50-66. CrossRef Medline

Riethmacher D, Sonnenberg-Riethmacher E, Brinkmann V, Yamaai T, Lewin GR, Birchmeier C (1997) Severe neuropathies in mice with targeted mutations in the ErbB3 receptor. Nature 389:725-730. CrossRef Medline

Riley DA (1981) Ultrastructural evidence for axon retraction during the spontaneous elimination of polyneuronal innervation of the rat soleus muscle. J Neurocytol 10:425-440. CrossRef Medline

Robitaille R (1998) Modulation of synaptic efficacy and synaptic depression by glial cells at the frog neuromuscular junction. Neuron 21:847-855. CrossRef Medline

Roche SL, Sherman DL, Dissanayake K, Soucy G, Desmazieres A, Lamont DJ, Peles E, Julien JP, Wishart TM, Ribchester RR, Brophy PJ, Gillingwater TH (2014) Loss of glial neurofascin 155 delays developmental synapse elimination at the neuromuscular junction. J Neurosci 34:12904-12918. CrossRef Medline

Rotundo RL, Ruiz CA, Marrero E, Kimbell LM, Rossi SG, Rosenberry T, Darr A, Tsoulfas P (2008) Assembly and regulation of acetylcholinesterase at the vertebrate neuromuscular junction. Chem Biol Interact 175:26-29. CrossRef Medline

Ruegg MA, Tsim KW, Horton SE, Kröger S, Escher G, Gensch EM, McMahan UJ (1992) The agrin gene codes for a family of basal lamina proteins that differ in function and distribution. Neuron 8:691-699. CrossRef Medline

Sanes JR, Lichtman JW (2001) Induction, assembly, maturation and maintenance of a postsynaptic apparatus. Nat Rev Neurosci 2:791-805. CrossRef Medline

Sathyamurthy A, Yin DM, Barik A, Shen C, Bean JC, Figueiredo D, She JX, Xiong WC, Mei L (2015) ERBB3-mediated regulation of Bergmann glia proliferation in cerebellar lamination. Development 142:522-532. CrossRef Medline

Schwander M, Shirasaki R, Pfaff SL, Müller U (2004) Betal integrins in muscle, but not in motor neurons, are required for skeletal muscle innervation. J Neurosci 24:8181-8191. CrossRef Medline

Sepp KJ, Schulte J, Auld VJ (2001) Peripheral glia direct axon guidance across the CNS/PNS transition zone. Dev Biol 238:47-63. CrossRef Medline

Shen C, Lu Y, Zhang B, Figueiredo D, Bean J, Jung J, Wu H, Barik A, Yin DM, Xiong WC, Mei L (2013) Antibodies against low-density lipoprotein receptor-related protein 4 induce myasthenia gravis. J Clin Invest 123: 5190-5202. CrossRef Medline

Smith IW, Mikesh M, Lee Yi, Thompson WJ (2013) Terminal Schwann cells 
participate in the competition underlying neuromuscular synapse elimination. J Neurosci 33:17724-17736. CrossRef Medline

Son YJ, Thompson WJ (1995a) Nerve sprouting in muscle is induced and guided by processes extended by Schwann cells. Neuron 14:133-141. CrossRef Medline

Son YJ, Thompson WJ (1995b) Schwann cell processes guide regeneration of peripheral axons. Neuron 14:125-132. CrossRef Medline

Strochlic L, Falk J, Goillot E, Sigoillot S, Bourgeois F, Delers P, Rouvière J, Swain A, Castellani V, Schaeffer L, Legay C (2012) Wnt4 participates in the formation of vertebrate neuromuscular junction. PLoS One 7:e29976. CrossRef Medline

Tapia JC, Wylie JD, Kasthuri N, Hayworth KJ, Schalek R, Berger DR, Guatimosim C, Seung HS, Lichtman JW (2012) Pervasive synaptic branch removal in the mammalian neuromuscular system at birth. Neuron 74: 816-829. CrossRef Medline

Tessier-Lavigne M, Goodman CS (1996) The molecular biology of axon guidance. Science 274:1123-1133. CrossRef Medline

Todd KJ, Darabid H, Robitaille R (2010) Perisynaptic glia discriminate patterns of motor nerve activity and influence plasticity at the neuromuscular junction. J Neurosci 30:11870-11882. CrossRef Medline

Turney SG, Lichtman JW (2012) Reversing the outcome of synapse elimination at developing neuromuscular junctions in vivo: evidence for synaptic competition and its mechanism. PLoS Biol 10:e1001352. CrossRef Medline

Ullian EM, Sapperstein SK, Christopherson KS, Barres BA (2001) Control of synapse number by glia. Science 291:657-661. CrossRef Medline

Ullian EM, Harris BT, Wu A, Chan JR, Barres BA (2004) Schwann cells and astrocytes induce synapse formation by spinal motor neurons in culture. Mol Cell Neurosci 25:241-251. CrossRef Medline

Walsh MK, Lichtman JW (2003) In vivo time-lapse imaging of synaptic takeover associated with naturally occurring synapse elimination. Neuron 37:67-73. CrossRef Medline

Wanner IB, Mahoney J, Jessen KR, Wood PM, Bates M, Bunge MB (2006) Invariant mantling of growth cones by Schwann cell precursors characterize growing peripheral nerve fronts. Glia 54:424-438. CrossRef Medline

Wichterle H, Lieberam I, Porter JA, Jessell TM (2002) Directed differentia- tion of embryonic stem cells into motor neurons. Cell 110:385-397. CrossRef Medline

Woldeyesus MT, Britsch S, Riethmacher D, Xu L, Sonnenberg-Riethmacher E, Abou-Rebyeh F, Harvey R, Caroni P, Birchmeier C (1999) Peripheral nervous system defects in erbB2 mutants following genetic rescue of heart development. Genes Dev 13:2538-2548. CrossRef Medline

Wu H, Xiong WC, Mei L (2010) To build a synapse: signaling pathways in neuromuscular junction assembly. Development 137:1017-1033. CrossRef Medline

Wu H, Lu Y, Shen C, Patel N, Gan L, Xiong WC, Mei L (2012) Distinct roles of muscle and motoneuron LRP4 in neuromuscular junction formation. Neuron 75:94-107. CrossRef Medline

Wu H, Barik A, Lu Y, Shen C, Bowman A, Li L, Sathyamurthy A, Lin TW, Xiong WC, Mei L (2015) Slit2 as a beta-catenin/Ctnnb1-dependent retrograde signal for presynaptic differentiation. eLife 4.

Yang JF, Cao G, Koirala S, Reddy LV, Ko CP (2001) Schwann cells express active agrin and enhance aggregation of acetylcholine receptors on muscle fibers. J Neurosci 21:9572-9584. Medline

Yang X, Arber S, William C, Li L, Tanabe Y, Jessell TM, Birchmeier C, Burden S) (2001) Patterning of muscle acetylcholine receptor gene expression in the absence of motor innervation. Neuron 30:399-410. CrossRef Medline

Yin X, Kidd GJ, Pioro EP, McDonough J, Dutta R, Feltri ML, Wrabetz L, Messing A, Wyatt RM, Balice-Gordon RJ, Trapp BD (2004) Dysmyelinated lower motor neurons retract and regenerate dysfunctional synaptic terminals. J Neurosci 24:3890-3898. CrossRef Medline

Yumoto N, Kim N, Burden SJ (2012) Lrp4 is a retrograde signal for presynaptic differentiation at neuromuscular synapses. Nature 489:438-442. CrossRef Medline

Zhang B, Luo S, Wang Q, Suzuki T, Xiong WC, Mei L (2008) LRP4 serves as a coreceptor of agrin. Neuron 60:285-297. CrossRef Medline

Zhang B, Liang C, Bates R, Yin Y, Xiong WC, Mei L (2012) Wnt proteins regulate acetylcholine receptor clustering in muscle cells. Mol Brain 5:7. CrossRef Medline

Zong Y, Zhang B, Gu S, Lee K, Zhou J, Yao G, Figueiredo D, Perry K, Mei L, Jin R (2012) Structural basis of agrin-LRP4-MuSK signaling. Genes Dev 26:247-258. CrossRef Medline 